


\title{
The ecology of Australopithecus anamensis in the early Pliocene of Kanapoi, Kenya
}

René Bobe a,b,c, Fredrick Kyalo Manthi d, Carol V. Ward e, Michael Plavcan f, Susana Carvalho a,b,c,g

a Primate Models for Behavioural Evolution Lab, Institute of Cognitive \& Evolutionary Anthropology, School of Anthropology, University of Oxford, Oxford, UK ${ }^{\mathrm{b}}$ Gorongosa National Park, Sofala, Mozambique

${ }^{c}$ Interdisciplinary Centre for Archaeology and Evolution of Human Behaviour (ICArEHB), Universidade do Algarve, Faro, Portugal

${ }^{\mathrm{d}}$ Department of Earth Sciences, National Museums of Kenya, Nairobi, Kenya

${ }^{\mathrm{e}}$ Department of Pathology and Anatomical Sciences, University of Missouri, Columbia, MO, USA

${ }^{f}$ Department of Anthropology, University of Arkansas, Fayetteville, AR, USA

${ }^{g}$ Centre for Functional Ecology, University of Coimbra, Coimbra, Portugal

Keywords: hominin paleoecology; paleoenvironments; eastern Africa; faunal analysis

\begin{abstract}
Australopithecus anamensis is a pivotal species in human evolution. It is likely the direct ancestor of Australopithecus afarensis and the species that may have given rise to the Homo and Paranthropus lineages. It had a suite of adaptations for habitual bipedalism and a diet that differed from that of earlier hominin species. Under what environmental and ecological conditions did this suite of adaptations arise? The early Pliocene site of Kanapoi in the Lake Turkana Basin of Kenya has the largest sample of A. anamensis in eastern Africa, and a rich record of fossil vertebrates. Most Kanapoi fossils are chronologically well constrained by radiometrically dated tephras between the ages of 4.2 and 4.1 million years ago. Sedimentological, isotopic, and faunal data indicate that the environments of Kanapoi during the early Pliocene had a complex range of vegetation types that included closed woodlands, shrubs, and grasslands near a river (for most of the sequence) or lake. These were dynamic landscapes that could shift rapidly from fluvial to lacustrine conditions, and then back. A. anamensis shared its environments with at least ten species of very large herbivores, which undoubtedly played a major role in modifying the landscape by opening wooded areas and providing pathways for bipedal hominins. Hominins may have competed for terrestrial resources with abundant suids (Nyanzachoerus and Notochoerus), and for arboreal resources with monkeys (with Parapapio as the most common cercopithecid). Kanapoi had a formidable suite of predators that included a very abundant species of hyena (Parahyaena howelli), two sabre-tooth felids (Dinofelis and Homotherium), a giant otter (Enhydriodon cf. dikikae), and three species of crocodiles. Various measures of abundance indicate that A. anamensis was
\end{abstract}


an important component of the Kanapoi early Pliocene ecosystems, and that its key adaptations allowed this species to thrive in complex and dynamic landscapes.

\section{Introduction}

Relative to earlier hominins, the genus Australopithecus is characterized by specialized postcanine teeth with thick molar enamel, as well as postcranial adaptations to habitual terrestrial bipedalism (White et al., 2006). The genus, first described by Raymond Dart (1925), is thought to represent the grade or adaptive plateau from which later hominins evolved (White et al., 2009) (Fig. 1). Thus, Australopithecus has a pivotal position in human evolution. Understanding the environments and ecological context of early Australopithecus is key for answering questions about how and why some of its derived adaptations first evolved. Australopithecus anamensis from the early Pliocene of eastern Africa is currently considered to be the earliest species of the genus. Originally, A. anamensis was named and described based on specimens from the Kenyan sites of Kanapoi and Allia Bay in the Lake Turkana Basin (Leakey et al., 1995; Leakey et al., 1998; Ward et al., 2001) (Fig. 2). Subsequently, important specimens of A. anamensis were found at Asa Issie in the Middle Awash Valley of Ethiopia (White et al., 2006), and most recently in the Woranso-Mille research area of the Afar (Haile-Selassie et al., 2019; Saylor et al., 2019). Specimens tentatively attributed to A. anamensis also derive from the sites of Galili (Kullmer et al., 2008) and Fejej (Fleagle et al., 1991; Ward, 2014) in Ethiopia (Fig. 2). The hominins from these sites (Kanapoi, Allia Bay, Asa Issie, Woranso-Mille, Galili, Fejej) date between 4.2 Ma and 3.8 Ma. There are other important paleontological sites in Africa from this time interval, e.g. Kollé in Chad (Brunet et al., 1998; Geraads et al., 2009; Lebatard et al., 2010), the Mursi Formation in southern Ethiopia (Drapeau et al., 2014), the Tugen Hills sites in Kenya (Chemeron Formation) (Hill, 2002), the Lower Laetolil Beds at Laetoli (Harrison, 2011) and the Manonga Valley in Tanzania (Harrison, 1997), but these have not yielded hominins from this time (Table 1). At Lothagam, to the north of Kanapoi, the Apak Member of the Nachukui Formation has yielded a single hominin of uncertain 
taxonomic affinities and dated to more than 4.3 Ma (McDougall and Brown, 2008; McDougall and Feibel, 1999). The largest sample of $A$. anamensis derives from Kanapoi, currently with 74 individuals attributed to this species, including males and females, adults and juveniles, cranial and postcranial elements (Ward et al., 2001; Ward et al., 2017). These fossils show that $A$. anamensis had a high degree of sexual dimorphism in body mass, comparable to that of the later species A. afarensis (Ward et al., 2001). Kanapoi also has a large sample of fossil mammals (Harris and Leakey, 2003), many of them described in this Special Issue (Boisserie, 2017; Frost et al., In press; Geraads, 2017; Geraads and Bobe, 2017a, b; Gunnell and Manthi, 2018; Sanders, 2019; Werdelin and Lewis, 2017; Winkler and Manthi, In press), along with other taxa including crocodiles (Brochu, 2017), birds (Field, 2017), squamates (Head and Müller, 2018), anurans (Delfino, 2017), fishes (Stewart and Rufolo, 2018), and mollusks (Van Bocxlaer, 2017). Many of the mammalian specimens have also been analyzed for dental enamel stable isotopes (Manthi et al., 2017), microwear (Ungar et al., 2017), and mesowear (Dumouchel and Bobe, 2019). The Kanapoi fossil record thus presents a unique opportunity to analyze the environmental and ecological context of the earliest species of the genus Australopithecus, and to understand how and why some of its key adaptations may have first evolved. Here we draw from the papers published in this Special Issue, and contribute new data and interpretations to provide a synthesis of the paleoenvironmental, paleontological, and paleoecological context of Australopithecus anamensis in the early Pliocene of Kanapoi.

\section{Brief history of research at Kanapoi}

In 1964, Bryan Patterson of Harvard University initiated geological and paleontological surveys between the Kerio and Turkwel rivers in the southwest of Lake Turkana, Kenya. Focusing on Kanapoi from 1965 to 1967, Patterson and colleagues discovered a hominin distal humerus (KNM-KP 271) (Patterson and Howells, 1967) along with fossil suids (Cooke and Ewer, 1972), rhinocerotids (Hooijer and Patterson, 1972), equids (Hooijer and Maglio, 1974), and 
proboscideans (Maglio, 1973) among a total of 330 fossil vertebrates. In 1980, Dennis Powers published further details of the geological framework of Kanapoi and nearby Lothagam for his doctoral dissertation (Powers, 1980). From 1994 to 1997, a team from the National Museums of Kenya (NMK) led by Meave Leakey resumed paleontological and geological field work at Kanapoi, documenting important fossil hominins and naming the new species, Australopithecus anamensis (Leakey et al., 1995; Leakey et al., 1998; Ward et al., 2001). This work in the 1990s resulted in the recovery of 650 fossil vertebrates (Harris and Leakey, 2003). In 1994, excavations of the A. anamensis holotype, KNM-KP 29281, led to the discovery of Nzube's Mandible Site, a richly fossiliferous concentration of micromammals. In 1996, Leakey's team discovered and began excavations of the Bat Site, another rich concentration of micromammalian remains. In 2003, Fredrick Kyalo Manthi of the National Museums of Kenya conducted further excavations focused on both Nzube's Mandible Site and the Bat Site (Manthi, 2006, 2008), and recovered a sample of over 3500 micromammal fossils. In 2007, Manthi launched a new wave of field research at Kanapoi adding over 900 new vertebrate specimens to the fossil collection (Geraads et al., 2013; Manthi et al., 2012; Ward et al., 2013; Werdelin and Manthi, 2012) (and this volume). Kanapoi thus has the largest sample of fossil vertebrates in Africa from the time of A.anamensis.

\section{Geological and paleoenvironmental context}

Patterson (Patterson, 1966) provided an initial description of the Pliocene sedimentary sequence at Kanapoi, and subsequently designated this sequence as the Kanapoi Formation, but without a detailed description (Patterson et al., 1970). Powers (1980) offered a more comprehensive description of the geology of the lower Kerio Valley, including Kanapoi. With the naming of the species Australopithecus anamensis, Leakey and colleagues (Feibel, 2003; Leakey et al., 1995; Leakey et al., 1998) refined the stratigraphic and chronologic framework of the Kanapoi Formation. The sedimentological, stratigraphic, and chronological framework of the hominins is now well-established (Feibel, 2003; McDougall and 
Brown, 2008). The Kanapoi Formation consists of up to $60 \mathrm{~m}$ of fluvio-deltaic and lacustrine sediments resting on Mio-Pliocene basalts (Feibel, 2003). The ancestral Kerio River laid down deposits initially over topographically heterogeneous landscapes provided by the Mio-Pliocene lava flows. The volcanic basement provided significant environmental heterogeneity to the paleo-landscapes. Most of the Kanapoi Formation sediments accumulated between 4.3 and 3.9 Ma, but some sedimentation continued up to $3.4 \mathrm{Ma}$, the age of the Kalokwanya Basalt that caps the sequence (Feibel, 2003) (Fig. 3). The formation consists of a lower fluvial sequence, interrupted by a lacustrine episode, and followed by an upper fluvial sequence capped by the Kalokwanya Basalt. The lower fluvial sequence includes the lower pumiceous tuff, radiometrically dated to 4.195 Ma, and the upper pumiceous tuff, dated to 4.147 Ma (McDougall and Brown, 2008). This part of the sequence has well-developed paleosols with abundant fossils. In fact, most of the Australopithecus specimens (and other fossil mammals) derive from paleosols between the lower and upper pumiceous tephra, i.e. between 4.195 and 4.147 Ma. This lower fluvial sequence is abruptly interrupted by deposits of the Lonyumun Lake, at the top of which there are thick deltaic deposits of the Kanapoi Tuff, dated to 4.108 Ma (Feibel, 2003; McDougall and Brown, 2008). The deltaic distributary channel deposits of the Kanapoi Tuff are also fossiliferous. Nearly all Kanapoi fossils are constrained by the lower pumiceous tuff and the Kanapoi Tuff, thus between 4.195 and 4.108 Ma. The upper fluvial sequence capped by the Kalokwanya Basalt (3.4 Ma) also records a lacustrine episode about 3.6 Ma that corresponds to the Lokochot Lake (Feibel, 2003). The topmost strata of the formation consist of a sequence of massive cobble to pebble conglomerates, which cut deeply into the fluvial strata beneath. These conglomerates comprise largely silicic volcanics, which are often thinly interbedded with sands. Mudstones are uncommon in this upper part of the section, and by the top of the formation the depositional setting developed into gravel braidplains, which are overlain by the Kalokwanya basalts. This upper sequence has a sparse fossil record (Feibel, 2003; Wynn, 2000). 
The Kanapoi paleosols have been of particular interest because most of the hominin fossils derive from them. The well-developed vertisols formed in clay overbank deposits, and attest to significant seasonality in precipitation during the early Pliocene (Wynn, 2000). Paleosol stable isotopes indicate that these soils formed in woodland and woody grassland environments (Quinn and Lepre, 2019; Wynn, 2000), with a fraction of woody canopy cover of between $40 \%$ and $60 \%$ (Cerling et al., 2011; Manthi et al., 2017) (Fig. 4). Wynn's detailed study of paleosols provides strong evidence that early Australopithecus, at least at times, inhabited seasonal, low tree-shrub savanna habitats (Wynn, 2000). Compared to stable carbon isotopes from Asa Issie (White et al., 2006), values from Kanapoi are slightly more depleted, but not as depleted as those reported for the Mursi Formation (Drapeau et al., 2016). This indicates that the Pliocene Kanapoi Formation had environments that were more open than those in the Mursi Formation, but comparable to those from Asa Issie, at least with respect to the carbon stable isotope signature. The latest analysis of pedogenic carbonates indicates that environmental heterogeneity was a key feature of the Kanapoi paleoenvironments rather than an artifact of time averaging (Quinn and Lepre, 2019). Previous work on the ecological structure of the mammalian fauna from Kanapoi is consistent with the stable isotope analyses and indicates closed woodlands with areas of grassland during the early Pliocene (Harris et al., 2003).

The sedimentological and depositional context of the Kanapoi fossils indicates that nearly all specimens derive from the lower fluvial sequence and the lacustrinedeltaic sequence, i.e. between 4.195 Ma and 4.108 Ma. Most of the hominins and other mammals derive from paleosols in the lower fluvial sequence, including the micromammals from Nzube's Mandible Site and the Bat Site. A small proportion of the fauna derives from the upper fluvial sequence, i.e., younger than 4.108 Ma. Thus, most of the fossil record spans an interval of nearly 90,000 years.

Albeit important work has been carried out on the Kanapoi geological context and paleontological record, this Special Issue presents substantial new data that bears 
on our understanding of the environmental and ecological context of the earliest species of Australopithecus. Here, we present a synthesis of these new data with regard to their paleoecological and biogeographic implications. We also present the results of the first systematic paleontological surveys carried out at Kanapoi to ascertain the relative abundances of the main vertebrate groups. The key questions we aim to address are: 1) How did Australopithecus anamensis fit within the Kanapoi paleoenvironments and paleoecological relationships? 2) What does the fossil record indicate about the geographic distribution and biogeographic connections of Australopithecus anamensis and other Kanapoi species?

\section{Materials and methods}

\section{Collection methods and faunal abundance}

The Kanapoi fossils have been collected using various methods. The first consisted of paleontological teams spanning the outcrops usually in search of hominins, while also collecting the better-preserved or more "identifiable" vertebrates, but without systematic collection protocols applicable to all vertebrate groups. These broad paleontological surveys collected all hominins encountered on the surface and in situ. Hominin finds were typically followed by intensive surveys of the immediate area where the hominin was found to ensure that all elements or fragments thereof could be recovered. The intensive localized surveys included surface crawls, partial excavations, and dry-screening. Cercopithecids were also systematically collected, as well as carnivores and other specimens thought to be representative of the Kanapoi fauna, or useful for taxonomic, biostratigraphic, or paleoecological purposes. The most up-to-date database lists 1,880 fossil vertebrates collected by this method and accessioned by the National Museums of Kenya (specimens with KNM-KP prefix, followed by a number). Mammals constitute $89 \%$ of this collection (1672 specimens). The remainder is composed of crocodiles (50 specimens), birds (105 specimens), squamates (23 specimens), turtles (20 specimens), and fish (8 specimens). Table 2 provides the taxonomic list and available abundance data for all 
vertebrates and invertebrates identified in the Kanapoi Formation and accessioned by the National Museums of Kenya. The numbers of specimens in Table 2 are a modified form of NISP (total number of identified specimens) in the sense that specimens inferred to belong to a single individual animal count as one. For example, KNM-KP 29281, the Australopithecus anamensis holotype, consists of a mandible and a fragment of temporal bone, but both specimens are thought to belong to the same individual based on their context in the field and subsequent examination in the laboratory (Leakey et al., 1995). Thus, in Table 2 the two specimens of KNM-KP 29281 count as one.

Another method consisted of thorough excavation and collection using wetscreening of two particularly fossiliferous concentrations of micromammals: Nzube's Mandible Site and the Bat site (Manthi, 2006, 2008). These sites were first excavated by Meave Leakey's team in 1994-1997, and then by Kyalo Manthi in 2003, resulting in about 3,500 documented specimens of Rodentia, Lagomorpha, Chiroptera, Eulipotyphla, and Macroscelidea (Manthi, 2008; Winkler and Manthi, In press). Nzube's Mandible Site is of particular paleoanthropological interest because of its temporal and spatial proximity with the Australopithecus anamensis holotype, the mandible KNM-KP 29281 (Leakey et al., 1995). The micromammals from this site likely accumulated as owl prey in the form of disaggregated owl pellets (Manthi, 2008). Given that the taphonomic context of the micromammals is different from that of larger vertebrates, consisting mostly of larger mammals, these are analyzed separately. Micromammal species and their abundance in terms of numbers of specimens (when known) are provided in Table 2. Numerical counts refer only to the subset of micromammal specimens that are accessioned at the NMK.

The most recent fossil collection method used at Kanapoi is the systematic paleontological survey, or PaleoSurvey. During the 2013 and 2014 field seasons, we carried out 40 systematic paleontological surveys targeting the main depositional intervals: the lower fluvial sequence, the lacustrine-deltaic sequence, and the upper fluvial sequence. The aim of these surveys was to document all the fossils found on 
the surface across different depositional environments at Kanapoi. This information serves as a baseline with which to evaluate taphonomic issues, faunal abundances, and paleoecology. These surveys are transects covering a linear distance of about 100-200 $\mathrm{m}$ in which all fossil occurrences are recorded. Each survey would last for approximately one hour; thus the 40 surveys involved about 40 hours of observations. The surveys typically involved six observers |(range 5-7), one of which was responsible for writing down all fossil observations based on taxonomic assessment and skeletal element (e.g., equid tooth fragment, alcelaphin lower molar, crocodile tooth, hippo femur fragment, fish vertebra, etc.), as well as the number of specimens (Fig. 5). The starting and endpoint of each survey was recorded with GPS coordinates. Observers walked slowly between these points, keeping a distance of a few meters between each individual, paying close attention to the ground, and indicating each time they saw a fossil. Although all fossil occurrences were recorded, even if fragmentary, only a sub-set of fossils was collected for further evaluation in the laboratory. Complete mammalian teeth, complete or nearly complete mammalian postcranial elements, complete fish vertebrae, fish teeth, etc., fit the criteria for this selection. When GPS coordinates were available, we were able to also note specimens (e.g., hominins) that had been collected since the 1990s in the same area corresponding to the PaleoSurvey transects. Combining both data sets previously collected fossils with those documented in the surveys - provides a more complete view of the specimens found on the surface at Kanapoi. A full taphonomic analysis of these data is beyond the scope of this contribution and will be presented in a separate publication, but here we show a summary of the major taxonomic groups across the main depositional environments (Table 3, Fig. 6). We use chisquare tests to assess vertebrate abundances across the different depositional settings. For this we use PAST (Paleontological Statistics) software version 3.16 (Hammer et al., 2001).

Thus, we can summarize the different collection methods in three categories. 1) Broad paleontological surveys carried out since 1965 by various teams. These collections are likely biased toward hominins, monkeys, carnivores, and the better- 
preserved specimens of other taxa. These specimens are the basis for the abundance data in Table 2, and form the bulk of the accessioned Kanapoi collections at the NMK. 2) Excavation and wet-screening focused on the recovery of micromammals. These specimens have been published by Manthi and colleagues (Winkler, 2003; Manthi, 2008) and we discuss them here only briefly. 3) Systematic PaleoSurveys conducted during the 2013-2014 field seasons, reported here for the first time. These different collection methods produce different taxonomic abundances, as discuss below.

To gain a better understanding of the relative abundances of Australopithecus and other mammals at Kanapoi (to the exclusion of the micromammals from the excavated bone beds), we carried out an analysis of taxa represented only by mandibular or cranial elements, excluding isolated teeth, postcranial elements and fragments thereof. The assumption here is that cranial and mandibular elements were collected more consistently across all mammals than other skeletal elements (postcranial bones and their fragments, tooth fragments). For this tabulation we excluded micromammals of the orders Lagomorpha, Rodentia, Chiroptera, Eulipotyphla, and Macroscelidea, because their taphonomic context differs from that of the larger mammals (see above). To reduce taxonomic ambiguities, we include taxa identified to genus or tribe. The proportions of mammalian taxa based on cranial and mandibular elements are shown in Table 4 and Figure 7 . Thus, Table 4 is a subset of the specimens and abundances listed in Table 2. Although this method attempts to reduce collection biases so as to better estimate relative abundances, it is likely that hominins remain overrepresented in Table 4 and Figure 7 . This is because we can be sure that all hominin mandibular and cranial specimens were collected once identified in the field, but we can only assume this to be the case for other taxa.

\section{Temporal and spatial scales}


The methods discussed above provide different scales of temporal and spatial resolution in the analysis of fossil vertebrates. At the smallest scale, the excavations of Nzube's Mandible Site and the Bat Site represent the finest temporal resolution in the Kanapoi Formation, with bone beds in areas of a few squared meters. At the largest scale, the broad faunal surveys represent a time of at least 90,000 years and an area of about $30 \mathrm{~km}^{2}$. Faunal abundance and composition varies across these scales. As our focus is on A. anamensis, we seek to analyze paleoenvironments and paleoecology at scales relevant to this species, which, as a relatively large, highly terrestrial primate, could well have ranged over an area the size of Kanapoi. As a point of reference, modern chimpanzee communities living in mixed/open environments typically have home ranges larger than $30 \mathrm{~km}^{2}$ (Nakamura et al., 2013), and we may assume that groups of A. anamensis would have had ranges at least as large.

Previous analyses indicate that there are no significant differences in the fauna from the lower fluvial sequence to the lacustrine-deltaic sequence (Harris and Leakey, 2003). An exception to this generalization would be the sparse fossils that derive from the upper levels of the upper fluvial sequence (Fig. 3). Thus, most of the Kanapoi fossil record dates from about 4.2 to 4.11 Ma, spanning 90,000 years, and for some purposes it may be considered as a single analytical unit (Harris and Leakey, 2003).

\section{Ordination methods}

To place Kanapoi in the context of other sites in Africa, we analyzed bovid abundance data from sites in the time interval from 4.3 Ma to 3.8 Ma (Table 1, Table 5). Bovids are the most abundant family of mammals at Kanapoi, and they are ecologically informative. Along with Kanapoi, we included the Apak Member of the Nachukui Formation at Lothagam (Leakey and Harris, 2003), Mursi Formation (Drapeau et al., 2014), Asa Issie (White et al., 2006), the Chemeron Formation in the Tugen Hills (sites BPRP \#12, 125) (Goble, 2011), the Lower Laetolil Beds (Gentry, 
2011), the Kiloleli Member of the Wembere-Manonga Formation (Gentry, 1997), and the site of Kollé in Chad (Geraads et al., 2009). Some of the sites listed in Table 1 do not provide sufficient faunal data to include in this analysis. We carried out a correspondence analysis ordination using bovid tribal abundance data that could be comparable across these sites. The analysis distributed the eight fossil sites along the principal axes based on the composition and abundance of the bovid fauna (Fig. 8). For correspondence analysis we use PAST (Paleontological Statistics) software version 3.16 (Hammer et al., 2001). This analysis is presented in the Results and Discussion sections.

\section{Stable isotopes}

In this contribution we also discuss stable isotope data from the published literature with a focus on carbon isotopes $\left(\delta^{13} \mathrm{C}\right)$ for the interval from $5 \mathrm{Ma}$ to $3 \mathrm{Ma}$ in eastern Africa. We draw on published paleosol carbonate data from the Kanapoi Formation (Wynn, 2000), the Nawata Formation in Lothagam (Cerling et al., 2003), the Koobi Fora Formation in East Turkana, the Nachukui Formation in West Turkana, and the Shungura Formation in lower Omo Valley (Levin et al., 2011). We also discuss published data from dental enamel in mammals, again with a focus on stable carbon isotopes $\left(\delta^{13} \mathrm{C}\right)$ (Cerling et al., 2015; Cerling et al., 2013a; Cerling et al., 2013b; Manthi et al., 2017). We report the isotopic data in the standard parts per mil (\%o) notation (Fig. 9).

\section{Confidence intervals on first appearance datum}

The earliest appearance (first appearance datum) of Australopithecus anamensis is in the fossil record of Kanapoi and Asa Issie, although the Kanapoi specimens are slightly earlier, very close to 4.2 Ma. Here we put confidence intervals on the first appearance of $A$. anamensis using methods described in detail elsewhere (Bobe and Behrensmeyer, 2004; Bobe and Carvalho, 2019; Bobe and Leakey, 2009). If $A$. anamensis had originated in the Turkana Basin, how likely is it was present in the 
basin prior to its earliest record? To answer this question, we need to evaluate the abundance of the species in the fossil record, and the sample sizes prior to its earliest occurrence. For this, we use the most conservative amongst our abundance estimates for the relative abundance of A. anamensis: $1.3 \%$ of the mammalian fauna (using the PaleoSurvey data in Table 3). In the Turkana Basin, fossil samples predating Kanapoi derive from the Apak Member of the Nachukui Formation in the Lothagam area (Leakey and Harris, 2003). The Apak deposits predate those of Kanapoi, although there is some overlap between the lowermost Kanapoi Formation and the uppermost Apak Member (McDougall and Feibel, 1999). The Apak Member has a record of 166 fossil mammals, with some specimens deriving from the earliest part of the sequence, and others from the later parts. If we assume that this record is more or less evenly distributed throughout the Apak sequence, we may parse it into two, with about half the record from the earlier half of the sequence, and the other half from the later part. Using the methods described by Bobe and Carvalho (2019), we estimate the $95 \%$ confidence interval for the first appearance datum (FAD) of $A$. anamensis (Fig. 1).

\section{Results and preliminary discussion}

The Kanapoi fossil record: a synthesis

The Kanapoi fossil record (Table 2) represents 11 orders of mammals: Primates, Lagomorpha, Rodentia, Carnivora, Cetartiodactyla, Perissodactyla, Chiroptera, Eulipotyphla, Tubulidentata, Proboscidea, and Macroscelidea. These mammals are distributed among 29 families, 57 genera, and 69 species. Of the 29 mammalian families, only two are extinct, and both are in the Proboscidea: Gomphotheriidae and Deinotheriidae. Of the 57 genera of mammals, 23 are extinct (40\%). There is also a diverse record of fossil birds, with 10 orders of Aves represented by at least 59 specimens, while three crocodilian species made their home in the Kanapoi rivers and lakes. Squamates, although relatively rare, include two families of lizards (Scincidae and Varanidae) and four families of snakes (Pythonidae, Viperidae, 
Atractaspididae, and Colubridae). Testudines are represented by three families, two of them aquatic (Pelomedusidae and Trionychidae) and one terrestrial (Testudinidae). Frogs are rare in the African fossil record, but at Kanapoi anurans of the burrowing species Hemisus cf. marmoratus are relatively abundant. Fishes are abundant, particularly in the lacustrine and deltaic intervals. They are represented by 13 families that provide important information about the ecological characteristics of paleo-lake Lonyumun. There is also a rich record of Mollusca, with abundant gastropods and bivalves that further refine our understanding of the Pliocene Kanapoi paleoecology and paleoenvironments.

\section{Primates}

There are at least seven species of primates represented in the Kanapoi fossil sample (Table 2): Australopithecus anamensis, Parapapio cf. ado, Theropithecus sp. Nanopithecus browni, cf. Kuseracolobus, another indeterminate species of Colobinae, and cf. Galago. These are distributed across three families: Hominidae (Leakey et al., 1995; Leakey et al., 1998; Ward et al., 2001; Ward et al., 2013; Ward et al., 2017), Cercopithecidae (Frost et al., In press; Harris et al., 2003; Plavcan et al., 2019), and Galagidae (Harris et al., 2003).

It is noteworthy that hominids are nearly as abundant as cercopithecids. There are 74 specimens (distinct individuals) of Australopithecus anamensis, the largest sample of the species from any site (Ward et al., 2017). This constitutes $3.9 \%$ of all accessioned Kanapoi vertebrates at the National Museums of Kenya. Most hominins derive from paleosols in the lower fluvial sequence. Relatively robust mandibles, thick dental enamel, and habitual bipedalism characterize the species. It has pronounced sexual dimorphism in body size, but less so in canine size (Ward et al., 2001). An estimate from the tibia, KNM-KP 29285, indicates a body mass of about $46 \mathrm{~kg}$ (Grabowski et al., 2015). Dental microwear analyses indicate that $A$. anamensis relied on tough foods (Ungar et al., 2010), while stable isotopes are indicative of $\mathrm{C}_{3}$ dietary resources (Cerling et al., 2013b). The fact that $A$. anamensis is 
found elsewhere in the Turkana Basin (i.e., Allia Bay, Fejej) (Ward, 2014; Ward et al., 2001) and in the Afar (Asa Issie, Galili, Woranso-Mille) (Kullmer et al., 2008; White et al., 2006; Haile-Selassie et al., 2019), indicates that for hominins there would have been suitable biogeographic connections between Turkana and the Afar.

As with the hominins, most of the Cercopithecidae derive from the lower fluvial sequence and the lacustrine/deltaic sequence, i.e. from about 4.2 to $4.1 \mathrm{Ma}$, with only a few specimens coming from the upper fluvial sequence (Frost et al., In press). There are at least five species of Cercopithecidae represented in the Kanapoi sample: three species of Cercopithecinae and two of Colobinae. The most abundant cercopithecid is Parapapio cf. ado, a papionin similar to the species from the Upper Laetolil Beds in Tanzania, suggesting biogeographical connections between the Turkana Basin and the Laetoli region at 3.7-3.6 Ma (Frost et al., In press). The genus Theropithecus, a highly successful lineage of African primates during the Pliocene and Pleistocene, has its earliest record in Kanapoi. It is noteworthy that both Theropithecus and Australopithecus have their first appearance datum in Kanapoi. Both taxa continue to occur in the Turkana Basin after this first appearance: in the Lonyumun ( 4 Ma) and Lokochot (3.6-.3.4 Ma) members of the Koobi Fora Formation. Both taxa also appear in the Awash valley: Theropithecus at Wee-ee ( 3.9 Ma), and then at Woranso-Mille (3.8-3.6 Ma), Australopithecus at Asa Issie (4.12 Ma) and later in the Woranso-Mille fossil record (Frost et al., In press; HaileSelassie et al., 2019). Parallels between the evolution of Theropithecus and hominins have long been noted (Foley, 1993; Jolly, 1970) and deserve further exploration. The small cercopithecin Nanopithecus browni is documented by only two teeth and a distal humerus, but constitutes the earliest record of Cercopithecini in Africa (Frost et al., In press; Plavcan et al., 2019). The humerus is indicative of arboreal adaptations. Colobines are significantly less abundant than cercopithecines, making up about $22 \%$ of the cercopithecid sample, whereas at Asa Issie colobines outnumber cercopithecines by $4: 1$. 
Strepsirrhine primates are rare in the Pliocene fossil record of eastern Africa, even though one might expect the small, nocturnal galagos to have been relatively common in woodlands and shrubland environments. There is a single Kanapoi specimen attributed to cf. Galago: KNM-KP 30260, a mandible fragment with m2 described by Harris et al. (2003) and most likely belonging to a previously undescribed species (Harrison, 2010).

\section{Lagomorpha}

There are fifteen specimens of lagomorphs at Kanapoi, but none of the specimens allow for taxonomic identification below the subfamily level, Leporinae (Table 2) (Winkler and Manthi, In press). The earliest record of leporids in Africa derives from the Chorora Formation of Ethiopia (Suwa et al., 2015) and the Nawata Formation in Kenya (Winkler, 2003), with the genus Alilepus, dated to about 7.5 Ma. The leporid Serengetilagus is present in the Apak Member of the Nachukui Formation, with an age slightly older than the Kanapoi sequence. At Laetoli, Serengetilagus is present

but rare in the Lower Laetolil Beds and becomes very abundant in the Upper Laetolil Beds, where it constitutes about $38 \%$ of the mammalian fauna (Winkler and Tomida, 2011). The Kanapoi leporids could be congeneric with the Apak and Laetoli taxon (Winkler and Manthi, In press).

\section{Rodentia}

Most of the Kanapoi rodents derive from excavations and wet-sieving of Nzube's Mandible Site, stratigraphically between the lower and upper pumiceous tuffs, i.e., between 4.2 and 4.15 Ma. The rodents represent 4 families (Sciuridae, Nesomyidae, Muridae, and Hystricidae) and ten genera (Table 2) (Winkler and Manthi, In press). Saidomys is the only extinct genus among Kanapoi rodents. Among Sciuridae, the ground squirrel Xerus represents a new species, but remains to be fully described. This genus is most often associated with semi-arid habitats, but it is rare at the site. Modern Nesomyidae are a diverse group of endemic African rodents. There is a new 
species of the fat mouse Steatomys that remains to be fully described. Steatomys is the only genus of Kanapoi fossil rodent that is not also represented among the modern fauna of the region. Modern Steatomys are associated with wooded grasslands. Muridae is the most diverse family of rodents at the site, with seven genera represented: Acomys, Gerbilliscus, Aethomys, Lemniscomys, Mus, and Saidomys (Winkler and Manthi, In press). The most common species is the spiny mouse Acomys coppensi, originally described from Hadar in Ethiopia (Sabatier, 1982). Acomys is also the most commonly documented rodent in the modern Kanapoi landscapes (Manthi, 2008). It is indeed remarkable that the most common genus of rodent at Nzube's Mandible Site, and thus in close association with the holotype of Australopithecus anamensis, is also the most commonly found rodent in the modern environments. The largest rodents from Kanapoi are the porcupines, Hystrix, which may represent the same species as H. leakeyi from the Upper Laetolil Beds in Tanzania (Winkler and Manthi, In press).

\section{Carnivora}

There are five families of Carnivora represented in the Kanapoi fossil record: Mustelidae, Viverridae, Herpestidae, Hyaenidae, and Felidae (Table 2). There are at least three species of mustelids: the piscivorous Torolutra and two species of Enhydriodon, including the giant otter E. dikikae. Kanapoi is the only fossil site with two species of Enhydriodon (Werdelin and Lewis, 2017; Werdelin and Manthi, 2012). These mustelids are indicative of large and relatively stable bodies of water. Viverrids are represented by four specimens attributed to Genetta (Werdelin and Lewis, 2017), the genus of the modern genets. Herpestids are diverse in Africa today, with about 26 living species (Bininda-Emonds, 2013). There are two specimens of Helogale, the genus that includes the living dwarf mongooses (Werdelin and Lewis, 2017). Helogale is also present at Asa Issie (White et al., 2006). The earliest record of this genus is at Lemudong'o in southern Kenya ( $\sim 6 \mathrm{Ma}$ ), and Helogale is well documented in the Upper Laetolil Beds ( 3.6 Ma) (Werdelin and Lewis, 2017). Modern species of Helogale occur in open woodlands and grasslands 
with termitaries, and some populations can be found in semi-desert conditions (Van Rompaey, 2013). Among felids, Homotherium, Dinofelis, and Felis are represented. Kanapoi has the first appearance datum of Homotherium and Felis (Werdelin and Lewis, 2017). Among this diverse carnivore fauna, hyaenids are the most abundant: with 37 specimens of Parahyaena howelli (Werdelin and Lewis, 2017).

\section{Cetartiodactyla}

Bovids are the most abundant family of mammals at Kanapoi, and they are ecologically informative even at the tribe level. There are at least 12 species of Bovidae distributed among the tribes Tragelaphini, Bovini, Aepycerotini, Ovibovini, Hippotragini, Alcelaphini, Antilopini, "Neotragini”, and Cephalophini (Table 2) (Geraads and Bobe, 2017a; Geraads et al., 2013). There are only two fragmentary specimens that could belong to Reduncini. Boselaphini were relatively common in the earlier deposits of the Nawata Formation at Lothagam ( 7 to $6 \mathrm{Ma})$, but this tribe is absent from Kanapoi. The last appearance datum of Boselaphini in Africa is in the Apak Member of the Nachukui Formation, earlier than 4.3 Ma. The most abundant bovids at Kanapoi are the Tragelaphini, which are also the most abundant bovids at Asa Issie (White et al., 2006). Both sites share the species Tragelaphus cf. kyaloi, a further indication of biogeographical connections between the Turkana and Afar basins. Tragelaphins are also the most abundant bovids at Allia Bay, but not in the Mursi Formation, where Aepycerotini predominate. At Kanapoi, Tragelaphini were predominantly browsers $\left(\delta^{13} \mathrm{C}\right.$ mean $\left.=-8.1 \%\right)$, while Aepycerotini $\left(\delta^{13} \mathrm{C}\right.$ mean $=-1.9 \%$ ) and Alcelaphini $\left(\delta^{13} \mathrm{C}\right.$ mean $=1.5 \%$ ) were grazers (Manthi et al., 2017). In the Mursi Formation, however, Aepycerotini were browsers $\left(\delta^{13} \mathrm{C}\right.$ mean $=-11.0 \%$ ) (Drapeau et al., 2014). Thus, stable isotopes place Tragelaphini at one end member of the $\mathrm{C}_{3}-\mathrm{C}_{4}$ dietary spectrum and Alcelaphini at the other end. These two tribes also show significant differences in dental mesowear (Dumouchel and Bobe, 2019). 
Three species of browsing giraffids co-existed at Kanapoi: the large Giraffa jumae, the smaller G. pygmaea, and Sivatherium cf. hendeyi (Geraads and Bobe, 2017a). Sivatherium at this time was a browser, and thus the three giraffid species are indicative of arboreal vegetation.

Hippopotamid fossils are abundant at Kanapoi, probably as a result of high population densities and favorable preservation conditions in the early Pliocene. As semiaquatic megaherbivores, they are indicative of perennial bodies of water, and likely played an important role in shaping the paleoenvironments. Nearly all specimens are assigned to a species that is nearly identical to the hippopotamid from the Hadar Formation in Ethiopia, dating from 3.6 to $3 \mathrm{Ma}$ (Boisserie, 2017). The Kanapoi and Hadar specimens are provisionally referred to aff. Hippopotamus sp. cf. Hadar by Boisserie, until a thorough revision of the family can be finalized. Alongside this large hippo, there is evidence of a second, smaller species of the family, represented by a single specimen (Table 2). The coexistence of two hippo species in the Turkana Basin is also documented in the late Miocene Nawata Formation, where the abundant Archaeopotamus harvardi is accompanied by the smaller and more rare A. lothagamensis (Weston, 2003). The distribution of the larger hippopotamid species from Turkana to the Afar parallels that of Australopithecus anamensis, and is indicative of hydrological and biogeographic connections between the two regions.

Two species of Suidae have been documented at Kanapoi: Nyanzachoerus kanamensis and Notochoerus jaegeri (Geraads and Bobe, 2017b), with Nyanzachoerus about twice as common as Notochoerus (Table 2). It is possible that these fairly large terrestrial omnivores competed for resources with hominins. Biogeographically, it is noteworthy that the genus Kolpochoerus seems to be absent from the Omo-Turkana Basin at about $4 \mathrm{Ma}$, but it is present in contemporaneous sites in the Afar (White et al., 2006). This raises the question, why did Kolpochoerus not disperse between the Turkana and Afar regions at about $4 \mathrm{Ma}$, as did Nyanzachoerus, Notochoerus, Australopithecus, and hippopotamids? 
Perissodactyla

Kanapoi Perissodactyla include two families: Equidae and Rhinocerotidae (Table 2). No specimens of Chalicotheriidae have been identified at the site. Kanapoi equids are hypsodont $\mathrm{C}_{4}$ grazers (Cerling et al., 2015; Geraads, 2017), and thus are indicative of grasslands. However, the material is too incomplete for finer taxonomic assignments or biogeographic interpretations. Rhinocerotidae are represented by Diceros praecox and Ceratotherium mauritanicum, with Diceros tending toward a browsing diet and Ceratotherium toward a grazing diet. The separate lineages leading to the modern species of African rhinocerotids were already established by $4 \mathrm{Ma}$ (Geraads, 2017).

\section{Chiroptera}

There are more than 500 bat specimens recovered from Kanapoi, but only some of these have accession numbers and are thus counted in Table 2 (Gunnell and Manthi, 2018). Most of these derive from the Bat Site and Nzube's Mandible Site, but some specimens derive from other localities. The sample represents both fruit bats (Megachiroptera) and echolocating bats (Gunnell and Manthi, 2018). There are four species of fruit bats, Pteropodidae, each one represented by a single tooth. The genera Eidolon, Rousettus, and Micropteropus include living species, whereas the genus Turkanycteris represents an extinct taxon. Pteropodids feed on fruits and flowers, and typically roost in trees (Gunnell and Manthi, 2018). The families of echolocating bats at Kanapoi are the Emballonuridae, Nycteridae, and Molossidae, and consist of species that prey for insects in open patches between woodlands/forests or close to rivers (Gunnell and Manthi, 2018).

\section{Eulipotyphla}


African shrews have a sparse fossil record. In Kanapoi there are three genera of Soricidae represented (Crocidura, Suncus, and Myosorex), all of them in the subfamily Crocidurinae (Table 2), a group associated predominantly with tropical rain forests. However, it is likely that the African species of Crocidura and Suncus adapted to drier conditions (Butler, 2010). Myosorex indicates the presence of at least some moist and wooded habitats in the early Pliocene (Winkler and Manthi, In press).

\section{Tubulidentata}

The order Tubulidentata includes a single family, the Orycteropodidae, with a single living species, the aardvark, Orycteropus afer. There are only two postcranial elements among the Kanapoi fossils attributed to Orycteropus (Table 2), but these have not been described in detail. They may belong to the species known from the early Pliocene of Chad, Orycteropus djourabensis (Lehmann et al., 2004), but further work is needed to confirm this.

\section{Proboscidea}

The fossil record of Kanapoi Proboscidea is abundant and diverse, with three families represented: Deinotheriidae, Gomphotheriidae, and Elephantidae (Table 2) (Sanders, 2019). Deinotheriids are represented by seven specimens of Deinotherium bozasi. Deinotheres are the only proboscideans during this time that remain committed $\mathrm{C}_{3}$ browsers, and their presence is indicative of ample woody vegetation. Deinotherium continued to occur in the Omo-Turkana Basin until its last appearance in Member K of the Omo Shungura Formation, 1.4 Ma. Gomphotheriids are the least abundant proboscidean, with only two specimens of Anancus ultimus. One of the Anancus dental specimens has a $\delta^{13} \mathrm{C}$ grazing signature (-0.1\%), while the other indicates mixed feeding (-7.3\%o) (Manthi et al., 2017). The species A. ultimus was originally described from specimens at Laetoli, where it was found in sediments contemporaneous with (and younger than) those from Kanapoi (Sanders, 2011). 
Elephantids are the most abundant and diverse family, with three species:

Loxodonta adaurora, L. exoptata, and Elephas ekorensis. The holotype of L. adaurora is a skull and associated skeleton from Kanapoi. This species was widespread and has also been found in the Nkondo, Sagantole, Chemeron, Mursi, Shungura, Koobi Fora, and Nachukui formations (Sanders, 2019). L. exoptata was rare, but became common in the Upper Laetolil Beds. Both Loxodonta and Elephas had a diet with a significant $\mathrm{C}_{4}$ component, although some individuals indicate a mixed feeding strategy (Cerling et al., 2015; Cerling et al., 1999; Harris and Leakey, 2003).

\section{Macroscelidea}

The order Macroscelidea is endemic to Africa, and forms part of the supercohort or superorder Afrotheria. Modern sengis (sometimes called elephant-shrews) constitute several species of the family Macroscelididae. At Kanapoi there are 3 specimens identified to the genus Elephantulus, similar in size to the modern species E. rufescens, whose distribution today includes the Turkana region (Table 2) (Winkler and Manthi, In press). Modern species of this genus are primarily insectivorous, terrestrial, and restricted to semi-arid habitats; E. rufescens occurs in dry woodland, bushland, and grassland where there are thickets (Perrin and Rathbun, 2013).

Aves

Kanapoi has a significant collection of fossil birds comprising at least 10 families (Table 2) (Field, 2017). At the family level, the most common birds are the swifts (Apodidae), ostriches (Struthionidae), and storks (Ciconidae). Fields (2017) suggests that the 'giant' species of marabou stork, Leptoptilos cf. falconeri, a facultative scavenger, may have been in a long commensal ecological relationship with hominins. Kanapoi has a high proportion of aquatic birds (30\%), which stands in contrast with Aramis in the Afar, where aquatic birds comprise $4 \%$ of the avifauna (Louchart et al., 2009). The preponderance of aquatic birds indicates the 
presence of large bodies of slow-moving water near Kanapoi in the early Pliocene, in accordance with other lines of evidence (Field, 2017).

\section{Crocodylia}

The Omo-Turkana Basin, with its predominantly fluvial and lacustrine environments of deposition, preserves a rich fossil record of crocodylian evolution for the past 7 million years. Today, a single crocodile species inhabits the waters of the Omo River and Lake Turkana, the Nile crocodile, Crocodylus niloticus. But during the time of the Nawata Formation in the late Miocene of Lothagam, there were five species of crocodile, including the earliest record of the genus Crocodylus in eastern Africa (Storrs, 2003). Kanapoi preserves three crocodylian species (Table 2) (Brochu, 2017). The most abundant crocodylian is Crocodylus thorbjarnarsoni, a large, horned species that is also found in Pleistocene Turkana Basin sites, and is closely related to the Olduvai crocodylian C. anthropofagus (Brochu and Storrs, 2012). The long, slender-snouted Euthecodon is also common. There is a single specimen referred to Mecistops, the genus of the modern slender-snouted African crocodile. The higher abundance of Crocodylus and Euthecodon relative to the rare Mecistops is also found in the Nawata Formation at Lothagam, and is maintained in the Plio-Pleistocene Koobi Fora and Shungura formations (Brochu, 2017). Thus, in the Omo-Turkana Basin there were five crocodylian species in the late Miocene, and three species in the Pliocene and Early Pleistocene. This reduction from five to three species may have resulted from broader climatic and tectonic changes in eastern Africa (Feibel, 2011), but with three persistent lineages the Omo-Turkana Basin seems to have had a higher diversity of crocodylians than other eastern African Pliocene andPleistocene sites (Brochu, 2017).

\section{Squamata}

Head and Müller (2017) present the first description of the Squamata (lizards and snakes) from Kanapoi. The lizards are represented by skinks (Scincidae) and 
monitor lizards (Varanidae), while snakes (Serpentes) are represented by pythons (Pythonidae), vipers (Viperidae), elapoids (cf. Atractaspididae), and colubrids (Colubridae) (Table 2) (Head and Müller, 2018). The most abundant squamates are the genera Varanus and Python. There are no strictly arboreal taxa. Overall, the squamates are indicative of shrub savanna vegetation (Head and Müller, 2018).

\section{Testudines}

The Kanapoi fossil chelonians constitute three families, two of them aquatic (Pelomedusidae, Trionychidae), and the third one terrestrial (Testudinidae) (Harris and Leakey, 2003). Pelomedusids are the most common family, and specimens of aquatic species outnumber those of terrestrial ones by about 5 to 1 (Table 2). The abundance of aquatic turtles is consistent with the presence of rivers and lakes in the Pliocene of Kanapoi.

\section{Anura}

There are 95 accessioned specimens of fossil anurans from Kanapoi, about half of them belonging to the genus Hemisus (Table 2) (Delfino, 2017). These specimens are the first fossil evidence of this genus, which is endemic to Africa. The living species Hemisus marmoratus, the shovel-nosed frog, occurs in open plains across subSaharan Africa, where it typically lays its eggs underground at the end of the dry season. Individuals may spend much of the year buried underground, and this may explain their abundance at the site (Delfino, 2017). Their association with grassy savannas is indicative of this type of paleoenvironment.

\section{Actinopterygii}

Kanapoi has a rich record of fossil fishes (Table 2). Over 2,800 fossil fish elements were recovered during fieldwork in the 1990s (Stewart, 2003), and an additional 400+ elements were recovered during the 2012-2015 field seasons (Stewart and 
Rufolo, 2018). Many of these specimens have not received formal accession numbers at the National Museums of Kenya, and they are referred to by their field numbers. Species of Clarotes and Lates occur in the lower fluvial sequence, but most of the fish diversity is from the lacustrine and deltaic deposits, where there is an abundance of piscivorous and molluscivore taxa. The ecological characteristics of the fishes indicate that the paleo-lake Lonyumun was rather shallow but well oxygenated, and that the upper fluvial sequence was deposited by a deep and welloxygenated river (Stewart and Rufolo, 2018). As Stewart and Rufolo note, many of the Kanapoi taxa are shared with the site of Wadi Natrun in Egypt. This indicates that there were hydrological connections between the Turkana Basin and the River Nile drainage during the Pliocene. These connections would have been stronger during wet periods.

\section{Gastropoda}

Kanapoi fossil mollusks include gastropods and bivalves (Table 2). Among gastropods there are four families represented in the fossil collections: Viviparidae, Paludomidae, Thiaridae, and Bithyniidae (Van Bocxlaer, 2017). Most of the gastropod specimens (as most of the fish fossils) derive from the lacustrine-deltaic interval and are associated with the Kanapoi Tuff (4.108 Ma), but some specimens derive from the upper fluvial interval. The gastropod genera Cleopatra,Melanoides, and Bellamya are abundant. Bellamya and Gabbiella in particular require perennial and well oxygenated water (Van Bocxlaer, 2017).

\section{Bivalvia}

Kanapoi fossil bivalves include three families: Unionidae, Iridinidae, andEtheriidae (Van Bocxlaer, 2017). As with the gastropods, most of the bivalve specimens derive from the lacustrine and upper fluvial sequences. Etheria bioherms at Kanapoi form thick deposits, indicating a high abundance of these bivalves (Feibel, 2003). Among bivalves, the genera Coelatura and Pseudobovaria are intolerant of oxygen stress. 
Overall, the mollusks indicate perennial fresh and well-oxygenated waters. Van Bocxlaer suggests that the paleo-lake Lonyumun had large stretches of open fresh water, perhaps analogous to modern Lake Victoria (Van Bocxlaer, 2017).

\section{Faunal abundances}

To ascertain the relative abundances of the major groups of fossil vertebrates at Kanapoi, we carried out systematic paleontological surveys, or PaleoSurveys, across the three main depositional environments: lower fluvial sequence, lacustrine-deltaic sequence, and upper fluvial sequence (see Methods). The PaleoSurveys, carried out during the 2013-2014 field seasons, resulted in the documentation of 5,512 fossils from the surface exposures (Table 3). The PaleoSurveys show that the major taxonomic groups of vertebrates vary significantly in abundance between fluvial and lacustrine depositional environments (chi-square $=1116.3, p<0.0001)$ (Figure 6). Fossil mammals are relatively most abundant in the lower fluvial sequence, where they make up about $52 \%$ of the fossil vertebrates, and least abundant in the deltaic-lacustrine depositional environments, where they constitute only $11 \%$ of fossil vertebrates. In the lacustrine-deltaic sequence, fishes make up $48 \%$ of all vertebrates, followed by crocodiles (34\%), and turtles (mostly aquatic taxa) (8\%). Thus, aquatic fauna constitute $90 \%$ of all fossils from these sediments (Figure 6). Among these, there were 963 fossil mammals recovered during the 2013-2014 PaleoSurveys. If we include the 13 hominins that had been previously found in areas covered by the PaleoSurvey transects, we estimate that hominin abundance in the Kanapoi exposures is about $1.3 \%$ of the mammalian fauna.

Another way to estimate taxonomic relative abundances at Kanapoi is to focus on specimens that are more likely to have been systematically collected by the various research groups over the decades of research at the site (see Methods). In an analysis that includes only mammalian mandibles and cranial elements, to the exclusion of isolated or fragmentary teeth and postcranial elements, we find that the suid Nyanzachoerus is the most abundant mammalian genus at Kanapoi, followed by 
Tragelaphus, aff. Hippopotamus, Notochoerus, Gazella, and Parapapio (Table 4, Fig. 7). In this context, Australopithecus is the $7^{\text {th }}$ most abundant mammalian genus, comprising about $5 \%$ of all mammals. Even if this analysis does not rule out collection biases in favor of hominins, it is clear that Australopithecus was relatively abundant at Kanapoi. Our PaleoSurveys (see above) indicate that Australopithecus made up about $1.3 \%$ of mammals across the main environments of deposition. Among carnivores, hyenas were most abundant. It is also noteworthy that Australopithecus shared the Kanapoi paleoenvironments with at least 10 species of megaherbivores (Fig. 7). The implications of these results are discussed below.

\section{Correspondence analysis}

The composition and abundance of Kanapoi bovids can be visualized relative to other sites from the time of A. anamensis in Africa (Table 1). Only eight of the sites listed in Table 1 provide faunal abundance data comparable to that of Kanapoi. A correspondence analysis of bovid tribes across these eight sites shows that Kanapoi is near the center of the distribution along the two principal axes, which combined explain $77.3 \%$ of the variation (Fig. 8). Mursi and Asa Issie have a high abundance of Tragelaphini and Aepycerotini, and very low abundances (or absence) of other bovids. Thus, the lower left cluster in Figure 8 may represent the most wooded environments amongst these samples. In the upper right part of the graph, the Lower Laetolil Beds and the Kiloleli Member (Manonga) both have Alcelaphini as the most abundant bovid tribe, and may represent the most open sites, except perhaps for Kollé in Chad, where Reduncini make up about $82 \%$ of the bovids. The absence of hominins in the Lower Laetolil Beds and Manonga suggests that these sites may have been too open for $A$. anamensis, but sampling and taphonomic issues cannot be ruled out. Kanapoi, with abundant Tragelaphini, Alcelaphini, Antilopini, and Aepycerotini, seems to combine a wide mix of vegetation types to accommodate this diverse bovid fauna (see also discussion by Dumouchel and Bobe, 2019).

\section{Discussion}


Australopithecus anamensis is a pivotal species in our understanding of early hominin evolution (Fig. 1), and the site of Kanapoi (Table 1, Fig. 2) offers a rich source of information on the environments and ecology of the earliest species of Australopithecus. The Kanapoi Formation (Fig. 3) was deposited on a basement of Mio-Pliocene basalts that provided important topographic and habitat heterogeneity to the landscapes of these early hominins (Feibel, 2003). In the lower fluvial sequence ( 4.2 - 4.14 Ma), most Australopithecus specimens were found within paleosols that formed in the floodplain of the paleo-Kerio river. Wynn's study of paleosols shows that the early Pliocene Kanapoi landscape was highly seasonal and included a component of low tree and shrub vegetation along with $\mathrm{C}_{4}$ grasses (Fig. 4) (Wynn, 2000). The paleo-Kerio river likely formed an axis of abundant resources (fresh water, fishes, gallery forests) that attracted a wide range of animals to the region. Its waters were well oxygenated and had large species of catfish and Nile perch (Stewart and Rufolo, 2018). Mammals compose most of the fossil vertebrates from the lower fluvial sequence ( $52 \%$ ), followed by turtles, crocodiles, and fish (Fig. 6).

By about 4.14 Ma, the Omo-Turkana Basin began to fill with the largest lake in its known history, paleo-lake Lonyumun, which extended from Kanapoi in the south to the Mursi region in the north (Fig. 2, Fig. 3) (Feibel, 2011). Evidence from fossil fishes, gastropods, and bivalves indicates that this was a fresh water lake, well oxygenated, and rather shallow but with extensive areas of open water (Stewart and Rufolo, 2018; Van Bocxlaer, 2017). Lake deposits have abundant fish, mollusks, and crocodiles (Table 4, Fig. 6), and these taxa provide important information about the aquatic environments in the region, but most of the mammalian fossils, including hominins, derive from the lower fluvial sequence and deltaic deposits. As the lacustrine waters began to recede, the river delta entering the lake is documented by deposits of the Kanapoi Tuff, dated to 4.108 Ma (McDougall et al., 2012). Hominins and other mammals were also found in these deltaic deposits. The fossil record of the upper fluvial sequence is less abundant than that from lower in the 
sedimentary sequence, and crocodiles become the dominant vertebrates (Fig. 6). The paleo-Kerio river of the upper fluvial sequence was a fast-moving and deep river, with very large fishes (Stewart and Rufolo, 2018). The expansion and contraction of the paleo-lake Lonyumun undoubtedly had an important effect on the geography, vegetation, and fauna of the region, but there is little evidence of temporal changes in the composition of the mammalian community during this time (Harris and Leakey, 2003).

Shifting hydrological conditions and high seasonality were determinant in the environmental heterogeneity of the Kanapoi Pliocene ecosystem, and likely contributed to the long-lasting high biodiversity of this environment. This paleoenvironmental heterogeneity was likely enhanced by the abundant and diverse fauna of very large herbivores (Table 2, Fig. 7), including Elephas ekorensis, Loxodonta adaurora,Loxodonta exoptata,Deinotheriumbozasi,Anancus ultimus, Diceros praecox, Ceratotherium mauritanicum, Sivatherium cf. hendeyi, Giraffa jumae, and two species of Hippopotamidae (although one of the hippos was small and rare). This high diversity of very large mammals stands in sharp contrast with modern Africa, where in the entire continent there are only six surviving species of megaherbivores (with body mass greater than $\sim 1000 \mathrm{~kg}$ ), some of them on the brink of extinction. It is most likely that Australopithecus avoided direct interactions with these megaherbivores, but hominins probably benefited from the environmental heterogeneity they provided (Sanders, 2019). With five species of Proboscidea in the Pliocene of Kanapoi, we may say that Australopithecus lived in a proboscidean-dominated landscape (Bobe and Carvalho, 2018).

In this fluvio-lacustrine system, hominins had access to a wide range of environments, but they obtained most of their diet from $\mathrm{C}_{3}$ resources (Fig. 9) (Cerling et al., 2013b). The high diversity of Primates and Megachiroptera indicates that Kanapoi had an abundant supply of fruits, at least seasonally. Australopithecus anamensis was an omnivorous, highly terrestrial primate who also relied on trees for shelter and food. This hominin may have competed for resources with other 
terrestrial omnivores, among them the abundant suids of the species Nyanzachoerus kanamensis and Notochoerus jaegeri. There may have been competition also with monkeys for arboreal resources, i.e., fruits, sleeping sites. The fossil evidence shows that Australopithecus was almost as abundant as the cercopithecid Parapapio, and these two primates probably encountered each other frequently.

Kanapoi hominins also had to contend with a wide range of predators that shaped their "landscapes of fear". The most abundant carnivores were the hyenas, Parahyaena howelli, and hominins had to be aware of their movements, as hyenas would have presented a threat, especially to juvenile or lone individuals. Large felids like Homotherium and Dinofelis surely presented a threat. Snakes were also part of this terrestrial landscape, while enormous crocodiles dominated the waters.

Kanapoi has the largest sample of Australopithecus anamensis in Africa (Table 1, Table 2). The relatively high number of hominins, both in absolute terms and in relative abundance, shows that hominins thrived in the heterogeneous environments of Kanapoi in the early Pliocene. The systematic paleontological surveys (2013-2014 PaleoSurveys) indicate that hominins constitute about $1.3 \%$ of the fossil mammals on the sedimentary exposures, and our analysis of cranial and mandibular specimens (from the broader surveys) indicates that hominins constitute about $5 \%$ of the mammalian fauna. Even if these proportions are inflated because of collecting biases, they do indicate that hominins were an important component of the Pliocene fauna in this region of the rift valley. Hominins were also abundant in the contemporaneous site of Asa Issie, in the Afar of Ethiopia (White et al., 2006). There are 8 hominin individuals (30 specimens) from Asa Issie in a sample of about 540 identifiable vertebrate specimens, from an area subjected to $100 \%$ surface collection (White et al., 2006). This abundance of hominins, $\sim 1.5 \%$ of fossil vertebrates, indicates that $A$. anamensis was also an important part of the Pliocene fauna in the Afar during this time. 
Asa Issie and Kanapoi share the presence of Australopithecus anamensis, Parapapio, Kuseracolobus, Tragelaphus kyaloi, Nyanzachoerus kanamensis, Notochoerus jaegeri, Anancus, Deinotherium, and Elephas, among other mammals. These shared taxa are indicative of strong biogeographic connection between the Turkana Basin and the Afar region at about $4 \mathrm{Ma}$. Stable isotopes from paleosols also indicate that the vegetation structure would have been similar at both sites (Fig. 4), with a mix of $\mathrm{C}_{3}$ woodlands and $\mathrm{C}_{4}$ grasslands. But there are also interesting differences between these two sites. The suid Kolpochoerus deheinzelini occurs at Asa Issie, but there is no record of Kolpochoerus at Kanapoi. At Asa Issie, colobines are much more abundant than cercopithecines, while the opposite is true at Kanapoi. Among bovids, Tragelaphus and Aepyceros are common at both sites, but Asa Issie lacks Alcelaphini and Gazella, which are common at Kanapoi. Hippopotamids are rare at Asa Issie but abundant at Kanapoi. Asa Issie also lacks or has a sparse record of crocodiles, fishes, water birds, and freshwater gastropods, all of which are abundant at Kanapoi.

The abundance of A. anamensis in Kanapoi and Asa Issie indicates that this species may have been widely distributed from the Turkana Basin to the Afar. Specimens of A. anamensis have also been found at other sites geographically located between Kanapoi and Asa Issie: Allia Bay, Fejej, and possibly Galili (Table 1). However, there is no record of the species in sites farther south from the time between 4.2 and 3.8 Ma: the Chemeron Formation in the Tugen Hills, the Lower Laetolil Beds, and the Wembere-Manonga Formation in the Manonga Valley of Tanzania all lack hominins (Table 1). Nor are there hominins to the west at the site of Kolle from this time period in Chad. If $A$. anamensis was distributed from the Turkana Basin to the Afar, the Mursi Formation in the lower Omo Valley offers an illuminating exception. Mursi now has a fossil sample of about 700 identified vertebrates, including many of the taxa found at Kanapoi, e.g., the suids Nyanzachoerus kanamensis and Notochoerus jaegeri, the bovids Tragelaphus and Aepyceros, the rhinocerotids Ceratotherium and Diceros, the proboscideans Anancus, Deinotherium, and Loxodonta, but no hominins (Drapeau et al., 2017; Drapeau et al., 2014). One possible explanation for the absence of hominins in the Mursi site is the relatively small sample size, but if 
hominins had been as abundant in the Mursi paleolandscapes as they were at Kanapoi and Asa Issie, some would have been found among the 700 vertebrates. Another possibility is that the Mursi fossils predate the appearance of Australopithecus, but the Mursi suids are of comparable age as those from Kanapoi (Drapeau et al., 2014). A third possibility is that the Mursi environments were not the most adequate for hominin subsistence. There are faunal and isotopic indications that Mursi environments were wetter and more closed, with a higher proportion of $\mathrm{C}_{3}$ vegetation, than other early Pliocene sites in eastern Africa (Drapeau et al., 2014). The wet and closed Mursi paleoenvironments may have presented an environmental barrier to the hominins that were thriving to the south and to the north. It is entirely possible that hominins will be found in the Mursi Formation with continuing fieldwork, but it is likely that they will be rare. This pattern leads to the hypothesis that $A$. anamensis was better adapted to seasonal, mixed woodland/grassland environments like those sampled at Kanapoi (and Asa Issie) than wetter and more wooded habitats like those of the Omo Mursi Formation. This hypothesis can be tested with further documentation of contemporaneous sites with and without $A$. anamensis.

The correspondence analysis in Figure 8 reinforces the idea that Kanapoi had a wide range of environments to accommodate a diverse bovid fauna (Table 5). Placed near the center of the distribution along the two main axes, Kanapoi had a "balance" of bovid tribes (with the exception of Reduncini). In contrast, at Asa Issie and Mursi Tragelaphini and Aepycerotini represent $96 \%$ of all bovids. These two sites had the most wooded and closed environments amongst those analyzed here. The Tanzanian sites of Laetoli (LowerLaetolilBeds) and Manonga (Kiloleli Member) had the highest proportion of Alcelaphini (31\% of all bovids at Laetoli and 55\% at Manonga), and likely represent paleoenvironments with extensive grasslands. Tragelaphini were absent from these two Tanzanian sites. The site of Kollé in Chad stands out by the high relative abundance of Reduncini ( $82 \%$ of the bovid fauna), suggesting a prevalence of seasonally flooded grasslands. The sample from the Chemeron Formation (BPRP \#12, 125) is too small to draw any firm conclusions, 
and that of the Apak Formation predates Kanapoi, as shown by the presence of Boselaphini. The distribution of bovid tribes at Kanapoi supports other lines of evidence indicative of varied environments that included woodland and gallery forests, shrubs, and grasslands.

Although it is tempting to suggest that Australopithecus may have originated where we find its earliest record, especially if this record indicates a robust presence in the area, there are vast regions of Africa that remain unknown during the early Pliocene. The earliest species of Australopithecus may have originated in regions that remain to be sampled, or which have no sedimentary exposures of the right age, and from its place of origin it dispersed into the Turkana Basin. If Australopithecus had originated in the Turkana Basin, the fossil record prior to Kanapoi is sparse, with only 166 specimens in the Apak Member to document the interval from 4.2 to almost $5 \mathrm{Ma}$. This needs to be taken into account when considering the origin of Australopithecus (Fig. 1).

Nevertheless, it seems clear that Australopithecus anamensis thrived in the complex environments of the Kanapoi region, with abundant fresh water, fruit, a mix of $\mathrm{C}_{3}$ woodlands with $\mathrm{C}_{4}$ grasses, and a rich vertebrate fauna dominated by proboscideans among the larger mammals. Although it appears that A. anamensis was obtaining most of its food from $\mathrm{C}_{3}$ resources (Fig. 9), Kanapoi provided opportunities for hominins to explore the more open grasslands, and after 3.8 Ma eastern African Australopithecus began to take advantage of some of the grassland resources available in its environment all along.

\section{Conclusions}

The site of Kanapoi provides a window on the rich Pliocene environments in which the earliest species of the genus Australopithecus, A. anamensis, thrived between about4.2 and 4.1 Ma. Geological, sedimentological, isotopic, and faunal dataindicate that the Kanapoi paleoenvironments were highly heterogeneous, with important 
topographic relief, significant seasonality, an abundance of fresh water, and a rich aquatic and terrestrial fauna. There was a high diversity of megaherbivores that included five species of proboscideans. In a sense, Australopithecus anamensis lived in a proboscidean-dominated landscape. Among the Kanapoi fauna we can identify likely predators (hyenas, large felids, crocodiles, snakes) as well as possible competitors (suids, monkeys) of the early hominins. But these environments also offered hominins plenty of resources from the woodlands, and possibly from aquatic habitats. Although $\mathrm{C}_{4}$ grasslands were part of these early hominin environments, Australopithecus did not take advantage of grassland resources until after 3.8 Ma. The distribution of early Australopithecus and other mammals from the Turkana Basin to the Afar indicates that these two regions were biogeographically well connected in the early Pliocene, but there were also important differences between them. As terrestrial omnivores living in complex and dynamic environments, Australopithecus anamensis and its descendants were well suited to take advantage the rapidly changing landscapes of the eastern Africa Pliocene.

\section{Acknowledgements}

We would like to thank the many researchers from Kenya and beyond who have spent so much time and effort to document the rich fossil record of Kanapoi. We are grateful to the staff, curators, and directors of the National Museums of Kenya for providing access to the fossils and facilitating their study. For their participation in the Systematic Paleontological Surveys, we thank Daniel Kiruna, Jackson Dongol, Tony Moru, Samson Edipo, Daniel Kisuna, Laurence Dumouchel, Elisabeth Moffett, Kat Beck, and Sharon Kuo. Our field research with the West Turkana Paleo Project was supported by the Leakey Foundation, the Paleontological Scientific Trust (PAST) of South Africa, the National Science Foundation, and the University of Missouri Research Board. 


\section{FIGURES}

Figure 1: Time range (in Ma) of Pliocene and earliest Pleistocene hominin taxa. Australopithecus is a pivotal genus in hominin evolution, giving rise to later Paranthropus and Homo. Kanapoi samples the earliest species of this genus. The dashed line shows the $95 \%$ confidence interval on the first appearance datum of $A$. anamensis.

Figure 2: Geographic location of eastern African paleontological sites from the time interval 4.3-3.8 Ma. Red circles indicate sites with fossil hominins; white circles indicate sites with fossil mammals but no hominins. Base map from GeoMapApp (http://www.geomapapp.org/).

Figure 3: Schematic illustration of the Kanapoi Formation with its main tephra and depositional environments. Dated tephra in Ma (million years ago).

Figure 4: Paleosol stable isotopes from Kanapoi, the Omo Group Deposits (Shungura, Nachukui, and Koobi Fora formations), and key sites from the Afar (Asa Issie and Aramis). Circles represent $\delta^{13} \mathrm{C}$ values from different formations in the OmoTurkana Basin: Nawata, Kanapoi, Nachukui, Koobi Fora, and Shungura formations. Data from Wynn 2000, Cerling et al. 2003, White et al. 2006, Levin et al. 2011.

Figure 5: Systematic Paleontological Surveys, orPaleoSurveys, at Kanapoi aiming to document all the fossils found on the surface across different depositional environments (see Methods).

Figure 6: Relative taxonomic proportions of the main vertebrate taxa from systematic paleontological survey (PaleoSurveys) data across the lower fluvial sequence, the lacustrine-deltaic sequence, and the upper fluvial sequence. These intensive surveys were conducted during the 2013-2014 field seasons, and consisted of 40 transects across depositional environments. The vertebrate abundances across depositional settings vary significantly (chi-square $=1116.3, p<$ $0.0001)$.

Figure 7: Relative proportions of Kanapoi mammals based on cranial and mandibular specimens, with taxa identified at the genus or tribe level. Megaherbivores are indicated with dashed lines. The data derive from Table 4, which is a subset of Table 2 .

Figure 8: Correspondence analysis for the interval 4.3-3.8 Ma based on the abundance of bovid tribes (circles) across eight of the African sites (triangles) listed in Table 1.

Figure 9: Carbon stable isotope values of East African hominin specimens in the interval from $5 \mathrm{Ma}$ to $3 \mathrm{Ma}$. Ardipithecus and earliest Australopithecus have values 
consistent with diet based mainly on $\mathrm{C}_{3}$ resources. Beginning about $3.8 \mathrm{Ma}$, Australopithecus began to include a larger proportion of $\mathrm{C}_{4}$ resources in its diet. Data from Cerling et al., 2015; Cerling et al., 2013a; Cerling et al., 2013b; Manthi et al., 2017). 


\section{References}

Bininda-Emonds, O.R.P., 2013. Family Herpestidae: mongooses, in: Kingdon, J., Happold, D.C., Butynski, T.M., Hoffmann, M., Happold, M., Kalina, J. (Eds.), Mammals of Africa. Bloomsbury Publishing, London, pp. 293-295.

Bobe, R., Behrensmeyer, A.K., 2004. The expansion of grassland ecosystems in Africa in relation to mammalian evolution and the origin of the genus Homo. Palaeogeography, Palaeoclimatology, Palaeoecology 207, 399-420.

Bobe, R., Carvalho, S., 2018. The decline of Africa's largest mammals: Did hominins play a role in the loss of megaherbivores? Science 362, 892-893.

Bobe, R., Carvalho, S., 2019. Hominin diversity and high environmental variability in the Okote Member, Koobi ForaFormation, Kenya. Journal of Human Evolution 126, 91-105.

Bobe, R., Leakey, M.G., 2009. Ecology of Plio-Pleistocene mammals in the OmoTurkana Basin and the emergence of Homo, in: Grine, F.E., Fleagle, J.G., Leakey, R.E. (Eds.), The first humans: origins of the genus Homo. Springer, Dordrecht, pp. 173184.

Boisserie, J.-R., 2017. Hippopotamidae (Cetartiodactyla, Hippopotamoidea) from Kanapoi, Kenya, and the taxonomic status of the late early Pliocene hippopotamids from the Turkana Basin. Journal of Human Evolution.

Brochu, C.A., 2017. Pliocene crocodiles from Kanapoi, Turkana Basin, Kenya. Journal of Human Evolution.

Brochu, C.A., Storrs, G.W., 2012. A giant crocodile from the Plio-Pleistocene of Kenya, the phylogenetic relationships of Neogene African crocodylines, and the antiquity of Crocodylus in Africa. Journal of Vertebrate Paleontology 32, 587-602.

Brunet, M., Beauvilain, A., Geraads, D., Guy, F., Kasser, M., Mackaye, H.T., MacLatchy, L.M., Mouchelin, G., Sudre, J., Vignaud, P., 1998. Tchad: découverte d'une faune de mammifères du Pliocène inférieur. Comptes Rendus de l'Académie des Sciences Series IIA - Earth and Planetary Science 326, 153-158.

Butler, P.M., 2010. Neogene Insectivora, in: Werdelin, L., Sanders, W.J. (Eds.), Cenozoic mammals of Africa. University of California Press, Berkeley, pp. 573-580. 
Cerling, T.E., Andanje, S.A., Blumenthal, S.A., Brown, F.H., Chritz, K.L., Harris, J.M., Hart, J.A., Kirera, F.M., Kaleme, P., Leakey, L.N., Leakey, M.G., Levin, N.E., Manthi, F.K., Passey, B.H., Uno, K.T., 2015. Dietary changes of large herbivores in the Turkana Basin, Kenya from 4 to 1 Ma. Proceedings of the National Academy of Sciences 112, 11467-11472.

Cerling, T.E., Chritz, K.L., Jablonski, N.G., Leakey, M.G., Manthi, F.K., 2013a. Diet of Theropithecus from 4 to $1 \mathrm{Ma}$ in Kenya. Proceedings of the National Academy of Sciences 110, 10507-10512.

Cerling, T.E., Harris, J.M., Leakey, M.G., 1999. Browsing and grazing in elephants: the isotope record of modern and fossil proboscideans. Oecologia 120, 364-374.

Cerling, T.E., Harris, J.M., Leakey, M.G., 2003. Isotope paleoecology of the Nawata and Nachukui Formations at Lothagam, Turkana Basin, Kenya, in: Leakey, M.G., Harris, J.M. (Eds.), Lothagam: The Dawn of Humanity in Eastern Africa. Columbia University Press, New York, pp.605-624.

Cerling, T.E., Manthi, F.K., Mbua, E.N., Leakey, L.N., Leakey, M.G., Leakey, R.E., Brown, F.H., Grine, F.E., Hart, J.A., Kaleme, P., Roche, H., Uno, K.T., Wood, B.A., 2013b. Stable isotope-based diet reconstructions of Turkana Basin hominins. Proceedings of the National Academy of Sciences 110, 10501-10506.

Cerling, T.E., Wynn, J.G., Andanje, S.A., Bird, M.I., Korir, D.K., Levin, N.E., Mace, W., Macharia, A.N., Quade, J., Remien, C.H., 2011. Woody cover and hominin environments in the past 6 million years. Nature 476, 51-56.

Cooke, H.B.S., Ewer, R.F., 1972. Fossil Suidae from Kanapoi and Lothagam, northwestern Kenya. Bulletin of the Museum of Comparative Zoology 143, 149-296.

Dart, R., 1925. Australopithecus africanus: the man-ape of South Africa. Nature 115, 195-199.

Delfino, M., 2017. Early Pliocene anuran fossils from Kanapoi, Kenya, and the first fossil record for the African burrowing frog Hemisus (Neobatrachia: Hemisotidae). Journal of Human Evolution.

Drapeau, M., Wynn, J., Geraads, D., Dumouchel, L., Campisano, C., Bobe, R., 2017. Reinvestigating the 4 Ma Yellow Sands of the Mursi Formation, American Association of Physical Anthropologists Annual Meeting. American Journal of Physical Anthropology, New Orleans, p. 165. 
Drapeau, M.S.M., Bobe, R., Wynn, J.G., Campisano, C.J., Dumouchel, L., Geraads, D., 2014. The Omo Mursi Formation: A window into the East African Pliocene. Journal of Human Evolution 75, 64-79.

Drapeau, M.S.M., Wynn, J.G., Geraads, D., Dumouchel, L., Campisano, C.J., Bobe, R., 2016. Where they were not: What can the Mursi Formation tell us about early hominins habitat preferences?, The Canadian Association for Physical Anthropology. Canadian Association for Physical Anthropology, Peterborough, Ontario, p. 27.

Dumouchel, L., Bobe, R., 2019. Paleoecological implications of dental mesowear and hypsodonty in fossil ungulates from Kanapoi. Journal of Human Evolution.

Feibel, C.S., 2003. Stratigraphy and depositional setting of the Pliocene Kanapoi Formation, lower Kerio valley, Kenya, in: Harris, J.M., Leakey, M.G.(Eds.), Geology and vertebrate paleontology of the early Pliocene site of Kanapoi, northern Kenya. Natural History Museum of Los Angeles County, Los Angeles, pp. 9-20.

Feibel, C.S., 2011. A geological history of the Turkana Basin. Evolutionary Anthropology 20, 206-216.

Field, D.J., 2017. Preliminary paleoecological insights from the Pliocene avifauna of Kanapoi, Kenya: Implications for the ecology of Australopithecus anamensis. Journal of Human Evolution.

Fleagle, J.G., Rasmussen, D.T., Yirga, S., Bown, T., Grine, F.E., 1991. New hominid fossils from Fejej, Southern Ethiopia. Journal of Human Evolution 21, 145-152.

Foley, R., 1993. African terrestrial primates: the comparative evolutionary biology of Theropithecus and the Hominidae, in: Jablonski, N.G. (Ed.), Theropithecus: The Rise and Fall of a Primate Genus. Cambridge University Press, Cambridge, pp. 245-270.

Frost, S.R., Ward, C.V., Manthi, F.K., Plavcan, J.M., In press. Cercopithecid fossils from Kanapoi, West Turkana, Kenya (2007-2015).

Gentry, A.W., 1997. Fossil ruminants (Mammalia) from the Manonga Valley, Tanzania, in: Harrison, T. (Ed.), Neogene paleontology of the Manonga Valley, Tanzania. Plenum Press, New York, pp. 107-135.

Gentry, A.W., 2011. Bovidae, in: Harrison, T. (Ed.), Paleontology and Geology of Laetoli: Human Evolution in Context: Volume 2: Fossil Hominins and the Associated Fauna. Springer, Dordrecht, pp.363-465. 
Geraads, D., 2017. Perissodactyla (Rhinocerotidae and Equidae) from Kanapoi. Journal of Human Evolution.

Geraads, D., Blondel, C., Mackaye, H.T., Likius, A., Vignaud, P., Brunet, M., 2009. Bovidae (Mammalia) from the lower Pliocene of Chad. Journal of Vertebrate Paleontology 29, 923-933.

Geraads, D., Bobe, R., 2017a. Ruminants (Giraffidae and Bovidae) from Kanapoi. Journal of HumanEvolution.

Geraads, D., Bobe, R., 2017b. Suidae from Kanapoi. Journal of Human Evolution.

Geraads, D., Bobe, R., Manthi, F.K., 2013. New ruminants (Mammalia) from the Pliocene of Kanapoi, Kenya, and a revision of previous collections, with a note on the Suidae. Journal of African Earth Sciences 85, 53-61.

Goble, E.D., 2011. Paleontology of the Chemeron Formation, Tugen Hills, Kenya with emphasis on faunal shifts and precessional climatic forcing, Anthropology. Yale University, New Haven, p.415.

Grabowski, M., Hatala, K.G., Jungers, W.L., Richmond, B.G., 2015. Body mass estimates of hominin fossils and the evolution of human body size. Journal of Human Evolution 85, 75-93.

Gunnell, G.F., Manthi, F.K., 2018. Pliocene bats (Chiroptera) from Kanapoi, Turkana Basin, Kenya. Journal of Human Evolution.

Haile-Selassie, Y., Melillo, S.M., Vazzana, A., Benazzi, S., Ryan, T.M., 2019. A 3.8million-year-old hominin cranium from Woranso-Mille, Ethiopia. Nature 573, 214219.

Hammer, Ø., Harper, D.A., Ryan, P.D., 2001. PAST: Paleontological Statistics Software Package for Education and Data Analysis. Palaeontologia Electronica 4, 9.

Harris, J.M., Leakey, M.G., 2003. Geology and Vertebrate Paleontology of the Early Pliocene Site of Kanapoi, Northern Kenya, Contributions in Science. Natural History Museum of Los Angeles County, Los Angeles, p. 132.

Harris, J.M., Leakey, M.G., Cerling, T.E., Winkler, A.J., 2003. Early Pliocene tetrapod remains from Kanapoi, Lake Turkana Basin, Kenya, in: Harris, J.M., Leakey, M.G. (Eds.), Geology and vertebrate paleontology of the early Pliocene site of Kanapoi, 
northern Kenya. Natural History Museum of Los Angeles County, Los Angeles, pp. 39-113.

Harrison, T., 1997. Neogene paleontology of the Manonga Valley, Tanzania: a window into the evolutionary history of East Africa. Springer.

Harrison, T., 2010. Later Tertiary Lorisiformes, in: Werdelin, L., Sanders, W.J. (Eds.), Cenozoic mammals of Africa. University of California Press, Berkeley, pp. 333-349.

Harrison, T., 2011. Paleontology and Geology of Laetoli: Human Evolution in Context: Volume 2: Fossil Hominins and the Associated Fauna, in: Delson, E., Sargis, E.J. (Eds.), Vertebrate Paleobiology and Paleoanthropology. Springer, Dordrecht, p. 616.

Head, J.J., Müller, J., 2018. Squamate reptiles from Kanapoi: Faunal evidence for hominin paleoenvironments. Journal of Human Evolution.

Hill, A., 2002. Paleoanthropological research in the Tugen Hills, Kenya. Journal of Human Evolution 42, 1-10.

Hooijer, D., A., Maglio, V.J., 1974. Hipparions from the Late Miocene and Pliocene of northwestern Kenya. Zoologische verhandelingen 134, 1-34.

Hooijer, D.A., Patterson, B., 1972. Rhinoceroses from the Pliocene of northwestern Kenya. Bulletin of the Museum of Comparative Zoology 144, 1-26.

Jolly, C.J., 1970. The seed eaters: a new model for hominid differentiation based on a baboon analogy. Man 5, 5-26.

Kullmer, O., Sandrock, O., Viola, T.B., Hujer, W., Said, H., Seidler, H., 2008. Suids, elephantoids, paleochronology, and paleoecology of the Pliocene hominid site Galili, Somali Region, Ethiopia. Palaios 23, 452-464.

Leakey, M.G., Feibel, C.S., McDougall, I., Walker, A., 1995. New four-million-year-old hominid species from Kanapoi and Allia Bay, Kenya. Nature 376, 565-571.

Leakey, M.G., Feibel, C.S., McDougall, I., Ward, C.V., Walker, A., 1998. New specimens and confirmation of an early age for Australopithecus anamensis. Nature 393, 62-66.

Leakey, M.G., Harris, J.M., 2003. Lothagam: the dawn of humanity in eastern Africa. Columbia University Press, New York, p. 678. 
Lebatard, A.-E., Bourlès, D.L., Braucher, R., Arnold, M., Duringer, P., Jolivet, M., Moussa, A., Deschamps, P., Roquin, C., Carcaillet, J., Schuster, M., Lihoreau, F., Likius, A., Mackaye, H.T., Vignaud, P., Brunet, M., 2010. Application of the authigenic 10Be/9Be dating method to continental sediments: Reconstruction of the MioPleistocene sedimentary sequence in the early hominid fossiliferous areas of the northern Chad Basin. Earth and Planetary Science Letters 297, 57-70.

Lehmann, T., Vignaud, P., Mackaye, H.T., Brunet, M., 2004. A fossil aardvark (Mammalia, Tubulidentata) from the lower Pliocene of Chad. Journal of African Earth Sciences 40, 201-217.

Levin, N.E., Brown, F.H., Behrensmeyer, A.K., Bobe, R., Cerling, T.E., 2011. Paleosol carbonates from the Omo Group: Isotopic records of local and regional environmental change in East Africa. Palaeogeography, Palaeoclimatology, Palaeoecology 307, 75-89.

Louchart, A., Wesselman, H., Blumenschine, R.J., Hlusko, L.J., Njau, J.K., Black, M.T., Asnake, M., White, T.D., 2009. Taphonomic, avian, and small-vertebrate indicators of Ardipithecus ramidus habitat. Science 326, 66-664.

Maglio, V.J., 1973. Origin and evolution of the Elephantidae. Transactions of the American Philosophical Society 63, 1-149.

Manthi, F.K., 2006. The Pliocene micromammalian fauna from Kanapoi, northwestern Kenya, and its contribution to understanding the environment of Australopithecus anamensis, Archaeology. University of Cape Town, Cape Town.

Manthi, F.K., 2008. The taphonomy of the Pliocene microfauna from Kanapoi, northwestern Kenya. Journal of Taphonomy 6, 41-66.

Manthi, F.K., Cerling, T.E., Chritz, K.L., Blumenthal, S.A., 2017. Diets of mammalian fossil fauna from Kanapoi, northwestern Kenya. Journal of Human Evolution.

Manthi, F.K., Ward, C.V., Plavcan, J.M., 2012. New hominin fossils from Kanapoi, Kenya, and the mosaic evolution of canine teeth in early hominins. South African Journal of Science 108,9.

Manthi, F.K., Ward, C.V., Plavcan, J.M., In press. Introduction to Kanapoi: A Pliocene Hominin Site in West Turkana Kenya. Journal of Human Evolution.

McDougall, I., Brown, F.H., 2008. Geochronology of the pre-KBS Tuff sequence, Omo Group, Turkana Basin. Journal of the Geological Society 165, 549-562. 
McDougall, I., Brown, F.H., Vasconcelos, P.M., Cohen, B.E., Thiede, D.S., Buchanan, M.J., 2012. New single crystal 40Ar/39Ar ages improve time scale for deposition of the Omo Group, Omo-Turkana Basin, East Africa. Journal of the Geological Society $169,213-226$.

McDougall, I., Feibel, C.S., 1999. Numerical age control for the Miocene-Pliocene succession at Lothagam, a hominoid-bearing sequence in the northern Kenya Rift. Journal of the Geological Society of London 156, 731-745.

Nakamura, M., Corp, N., Fujimoto, M., Fujita, S., Hanamura, S., Hayaki, H., Hosaka, K., Huffman, M.A., Inaba, A., Inoue, E., Itoh, N., Kutsukake, N., Kiyono-Fuse, M., Kooriyama, T., Marchant, L.F., Matsumoto-Oda, A., Matsusaka, T., McGrew, W.C., Mitani, J.C., Nishie, H., Norikoshi, K., Sakamaki, T., Shimada, M., Turner, L.A., Wakibara, J.V., Zamma, K., 2013. Ranging behavior of Mahale chimpanzees: a 16 year study. Primates 54, 171-182.

Patterson, B., 1966. A new locality for early Pleistocene fossils in north-western Kenya. Nature 212,577-581.

Patterson, B., Behrensmeyer, A.K., Sill, W.D., 1970. Geology of a new Pliocene locality in northwestern Kenya. Nature 256, 279-284.

Patterson, B., Howells, W.W., 1967. Hominid humeral fragment from early Pleistocene of northwestern Kenya. Science 156, 64-66.

Perrin, M., Rathbun, G.B., 2013. Order Macroscelidea - sengis (elephant-shrews), in: Kingdon, J., Happold, D.C., Butynski, T.M., Hoffmann, M., Happold, M., Kalina, J. (Eds.), Mammals of Africa. Bloomsbury Publishing, London, pp. 258-260.

Plavcan, J.M., Ward, C.V., Kay, R.F., Manthi, F.K., 2019. A diminutive Pliocene guenon from Kanapoi, West Turkana, Kenya. Journal of Human Evolution 135, 102623.

Powers, D.W., 1980. Geology of Mio-Pliocene sediments of the lower Kerio river valley, Kenya, Department of Geological and Geophysical Sciences. Princeton University, Princeton, p. 165.

Quinn, R.L., Lepre, C.J., 2019. Revisiting the pedogenic carbonate isotopes and paleoenvironmental interpretation of Kanapoi. Journal of Human Evolution.

Sabatier, M., 1982. Les rongeurs du site pliocène a hominidés de Hadar (Éthiopie). Palaeovertebrata 12, 1-56. 
Sanders, W.J., 2011. Proboscidea, in: Harrison, T. (Ed.), Paleontology and Geology of Laetoli: Human Evolution in Context: Volume 2: Fossil Hominins and the Associated Fauna. Springer, Dordrecht, pp. 233-262.

Sanders, W.J., 2019. Proboscidea from Kanapoi, Kenya. Journal of Human Evolution.

Saylor, B.Z., Gibert, L., Deino, A., Alene, M., Levin, N.E., Melillo, S.M., Peaple, M.D., Feakins, S.J., Bourel, B., Barboni, D., Novello, A., Sylvestre, F., Mertzman, S.A., HaileSelassie, Y., 2019. Age and context of mid-Pliocene hominin cranium from WoransoMille, Ethiopia. Nature 573, 220-224.

Stewart, K., 2003. Fossil fish remains from the Pliocene Kanapoi site, Kenya, in: Harris, J.M., Leakey, M.G. (Eds.), Geology and Vertebrate Paleontology of the Early Pliocene Site of Kanapoi, Northern Kenya. Natural History Museum of Los Angeles County, Los Angeles, pp.21-38.

Stewart, K.M., Rufolo, S.J., 2018. Kanapoi revisited: Paleoecological and biogeographical inferences from the fossil fish. Journal of Human Evolution.

Storrs, G.W., 2003. Late Miocene-Early Pliocene crocodilian fauna of Lothagam, southwest Turkana Basin, Kenya, in: Leakey, M.G., Harris, J.M. (Eds.), Lothagam: The Dawn of Humanity in Eastern Africa. Columbia University Press, New York, pp. 137159.

Suwa, G., Beyene, Y., Nakaya, H., Bernor, R.L., Boisserie, J.-R., Bibi, F., Ambrose, S.H., Sano, K., Katoh, S., Asfaw, B., 2015. Newly discovered cercopithecid, equid and other mammalian fossils from the Chorora Formation, Ethiopia. Anthropological Science 123, 19-39.

Ungar, P.S., Abella, E.F., Burgman, J.H., Lazagabaster, I.A., Scott, J.R., Delezene, L.K., Manthi, F.K., Plavcan, J.M., Ward, C.V., 2017. Dental microwear and Pliocene paleocommunity ecology of bovids, primates, rodents, and suids at Kanapoi. Journal of Human Evolution.

Ungar, P.S., Scott, R.S., Grine, F.E., Teaford, M.F., 2010. Molar microwear textures and the diets of Australopithecus anamensis and Australopithecus afarensis. Philosophical Transactions of the Royal Society B: Biological Sciences 365, 3345.

Van Bocxlaer, B., 2017. Paleoecological insights from fossil freshwater mollusks of the Kanapoi Formation (Omo-Turkana Basin, Kenya). Journal of Human Evolution. 
Van Rompaey, H., 2013. Genus Helogale: dward mongooses, in: Kingdon, J., Happold, D.C., Butynski, T.M., Hoffmann, M., Happold, M., Kalina, J. (Eds.), Mammals of Africa. Bloomsbury Publishing, London, p. 365.

Ward, C.V., 2014. Taxonomic affinity of the Pliocene hominin fossils from Fejej, Ethiopia. Journal of Human Evolution 73, 98-102.

Ward, C.V., Leakey, M.G., Walker, A., 2001. Morphology of Australopithecus anamensis from Kanapoi and Allia Bay, Kenya. Journal of Human Evolution 41, 255368.

Ward, C.V., Manthi, F.K., Plavcan, J.M., 2013. New fossils of Australopithecus anamensis from Kanapoi, West Turkana, Kenya (2003-2008). Journal of Human Evolution 65, 501-524.

Ward, C.V., Plavcan, J.M., Manthi, F.K., 2017. New fossils of Australopithecus anamensis from Kanapoi, West Turkana, Kenya (2012-2015). Journal of Human Evolution.

Werdelin, L., Lewis, M.E., 2017. A contextual review of the Carnivora of Kanapoi. Journal of Human Evolution.

Werdelin, L., Manthi, F.K., 2012. Carnivora from the Kanapoi hominin site, northern Kenya. Journal of African Earth Sciences 64, 1-8.

Weston, E.M., 2003. Fossil Hippopotamidae from Lothagam, in: Leakey, M.G., Harris, J.M. (Eds.), Lothagam: The Dawn of Humanity in Eastern Africa. Columbia University Press, New York, pp.441-483.

White, T.D., Asfaw, B., Beyene, Y., Haile-Selassie, Y., Lovejoy, C.O., Suwa, G., WoldeGabriel, G., 2009. Ardipithecus ramidus and the paleobiology of early hominids. Science 326, 64-86.

White, T.D., WoldeGabriel, G., Asfaw, B., Ambrose, S., Beyene, Y., Bernor, R.L., Boisserie, J.-R., Currie, B., Gilbert, H., Haile-Selassie, Y., Hart, W.K., Hlusko, L.J., Howell, F.C., Kono, R.T., Lehmann, T., Louchart, A., Lovejoy, C.O., Renne, P.R., Saegusa, H., Vrba, E.S., Wesselman, H., Suwa, G., 2006. Asa Issie, Aramis and the origin of Australopithecus. Nature 440, 883-889.

Winkler, A., Manthi, F.K., In press. Rodents and other terrestrial small mammals from Kanapoi, northern Kenya. Journal of Human Evolution. 
Winkler, A.J., 2003. Rodents and lagomorphs from the Miocene and Pliocene of Lothagam, northern Kenya, in: Leakey, M.G., Harris, J.M. (Eds.), Lothagam: The Dawn of Humanity in Eastern Africa. Columbia University Press, New York, pp. 169-198.

Winkler, A.J., Tomida, Y., 2011. The lower third premolar of Serengetilagus praecapensis (Mammalia: Lagomorpha: Leporidae) from Laetoli, Tanzania, in: Harrison, T. (Ed.), Paleontology and Geology of Laetoli: Human Evolution in Context: Volume 2: Fossil Hominins and the Associated Fauna. Springer, Dordrecht, pp. 5566.

Wynn, J.G., 2000. Paleosols, stable carbon isotopes, and paleoenvironmental interpretation of Kanapoi, Northern Kenya. Journal of Human Evolution 39, 411432. 

Table 1: Key paleontological sites in Africa dating from 4.3 to $3.8 \mathrm{Ma}$

Site

Kollé
Woranso-Mille

Aramis

Asalssie
Galili

Mursi

Fejej
AlliaBay

AlliaBay
Lothagam
Kanapoi

Kanapoi
TugenHills

Lagetoli

Manonga

\section{Localities
KL00,KL2-KL14}

MRD

ARA-VP-14

ASI-VP-2, ASI-VP-5, HAN-VP-1

Yellow Sands, Cholo

KoobiForaFm, Lonnyumn-Moitimbs

Nachukui Fm, ApakMb

KanapoiFm

Chemeron Fm
LowerLaetoliliBeds

Wembere-Manonga Fm, Kilolelimb
Fj-4

Omo-TurkanaBasin Kenya

Omo-TurkanaBasin Kenya

BPRP\#12 (Arwanin), BPRP\#125 (Tabingar) Baringo $\quad$ Kenya

$\begin{array}{lll}\text { Kakesio } & \text { EyasiPlateau } & \text { Tanzania } \\ \text { Kiloeleli } 1 \text {-4,Ngofila 1-5, BerediS1-3 } & \text { Manonga Valley } & \text { Tanzania }\end{array}$

$\begin{array}{ll}\text { Region } & \text { Country } \\ \text { DjurabDesert } & \text { Chad } \\ \text { Afar } & \text { Ethiopia } \\ \text { Afar } & \text { Ethiopia } \\ \text { Afar } & \text { Ethiopia } \\ \text { Afar } & \text { Ethiopia } \\ \text { Omo-TurkanaBasin Ethiopia } \\ \text { Omo-Turkana Basin Ethiopia } \\ \text { Omo-Turkanaasin Kenya } \\ \text { Omo-TurkanaBasin Kenya } \\ \text { Omo-TurkanaBasin Kenya } \\ \text { Baringo } & \text { Kenya } \\ \text { Eyasislateau } & \text { Tanzania } \\ \text { Manonga Valley } & \text { Tanzania } \\ & \end{array}$

Age Dating methods

Be/Be,biochronology Hominini?

4.2-4.1 Ma Radioisotopic, tephracorrelations, paleomag Australopithecus anamensis White etal.2006

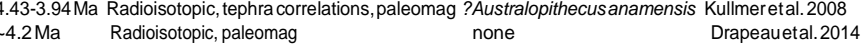

4 Madioisotopic

Ralisotopic

2-4.1 Ma Radioisotopic, biochronology, paleom

5.6-1.6 Ma Radioisotopic, biochronology, paleomag

4.35-3.85 Ma Radioisotopic

$\begin{array}{ll}.5-4 \mathrm{Ma} & \text { Biochronology } \\ & \end{array}$
Australopithecusanamensis Fleagle etal. 1991, Ward 2014

Australopithecus anamensis Leakey et al. 1995,1998
Homininiindet.

Australopithecus anamensis Kanapoi Special Issue

none Goble 2011

Harrison 2011

Harrison \& Baker 1997, Harrison \& Mbago 1997 
Table 2: Fossil taxa from the Kanapoi Formation, wi modified NISP

PRIMATES

HOMINIDAE

Australopithecus anamensis $\quad 74$

CERCOPITHECIDAE

Nanopithecus browni 2

Parapapio cf. ado $\quad 59$

Theropithecus sp. 6

cf. Kuseracolobus sp. 9

Colobinae gen. et sp. indet. $\quad 12$

GALAGIDAE

cf. Galago indet.

LAGOMORPHA

LEPORIDAE

Leporinae sp.

15

RODENTIA

SCIURIDAE

Xerus sp. nov.

NESOMYIDAE

Steatomys sp. nov.

MURIDAE

Acomys coppensi 52

Gerbilliscus sp. $\quad 16$

Aethomys sp.

Lemniscomys sp.

Mastomys sp.

cf. Mus sp.

Saidomys sp.

HYSTRICIDAE

Hystrix leakeyi

CARNIVORA

MUSTELIDAE

Mustelidae indet.

Enhydriodon ekecaman

Enhydriodon cf. dikikae

cf. Torolutra sp.

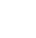

(n)

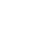

VIVERRIDAE

Viverridae indet. $\quad 6$

Genetta indet. 4

HERPESTIDAE

Helogale sp. 2

HYAENIDAE

Parahyaena howelli 37

Felidae indet. $\quad 5$

Dinofelis petteri 3

Homotherium sp. $\quad 5$

Felis sp. 2

CETARTIODACTYLA

BOVIDAE

Tragelaphini 
Table 3: Faunal abundance data from the 2013-2014 systematic paleontological surveys (PaleoSurveys) ac the lower fluvial sequence, the lacustrine-deltaic sequence, and the upper fluvial sequence.

\begin{tabular}{lrrr|r|} 
& Lower fluvial Lacustrine-deltaic & Upper fluvial & Total \\
\# of PaleoSurveys & 16 & 18 & 6 & 40 \\
& NISP & NISP & NISP & \\
\hline Fish & 149 & 1535 & 56 & 1740 \\
Crocodilian & 154 & 993 & 137 & 1284 \\
Chelonia & 181 & 232 & 19 & 432 \\
Mammalia & 524 & 314 & 125 & 963 \\
Vertebrate indet. & 491 & 452 & 103 & 1046 \\
Other (eg gastropods & 4 & 42 & 1 & 47 \\
\hline Total & 1503 & 3568 & 441 & 5512 \\
\hline
\end{tabular}


Table 4: Abundance of Kanapoi mammalian genera or tri These specimens are a subset of those in Table 1.

Taxon

Nyanzachoerus

mNISP $\quad \%$

Tragelaphus

$\begin{array}{ll}62 & 17.7\end{array}$

aff. Hippopotamus

$52 \quad 14.9$

Gazella

$23 \quad 6.6$

Notochoerus

$21 \quad 6.0$

Parapapio

21

6.0

Australopithecus

20

5.7

Elephas

18

5.1

Alcelaphini

14

4.0

Loxodonta

13

3.7

Parahyaena

13

3.7

Aepyceros

13

3.7

?Raphicerus

3.7

"Hipparion"

13

2.3

Ceratotherium

2.0

cf. Tchadotragus

2.0

Colobini indet.

1.7

Simatherium

1.4

cf. Kuseracolobus

0.9

Giraffa

0.9

Sivatherium

0.9

Genetta

0.9

Diceros

0.9

Deinotherium

0.9

?Reduncini

0.6

Theropithecus

0.6

Dytikodorcas

0.6

Ovibovini

0.3

Anancus

0.3

Dinofelis

0.3

Felis

Nanopithecus

0.3

cf. Galago

Helogale

0.3

0.3

Enhydriodon

0.3

0.3

aff. Hippopotamus sp. B

0.3

Total

0.3

350

100.0 
Table 5: Abundance data (numbers of specimens) for the correspondence analysis of bovid tribes across key African sites dating between 4.3 and $3.8 \mathrm{Ma}$

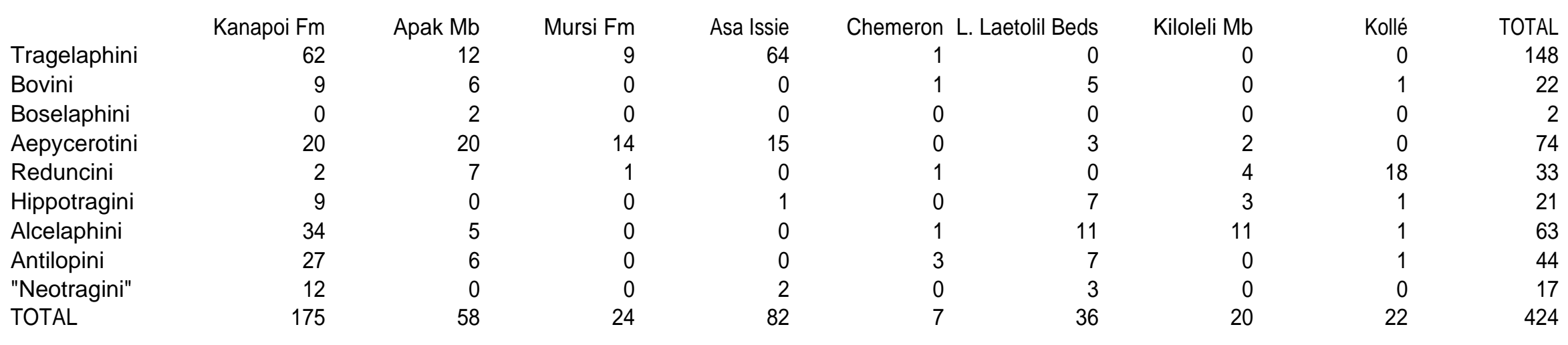




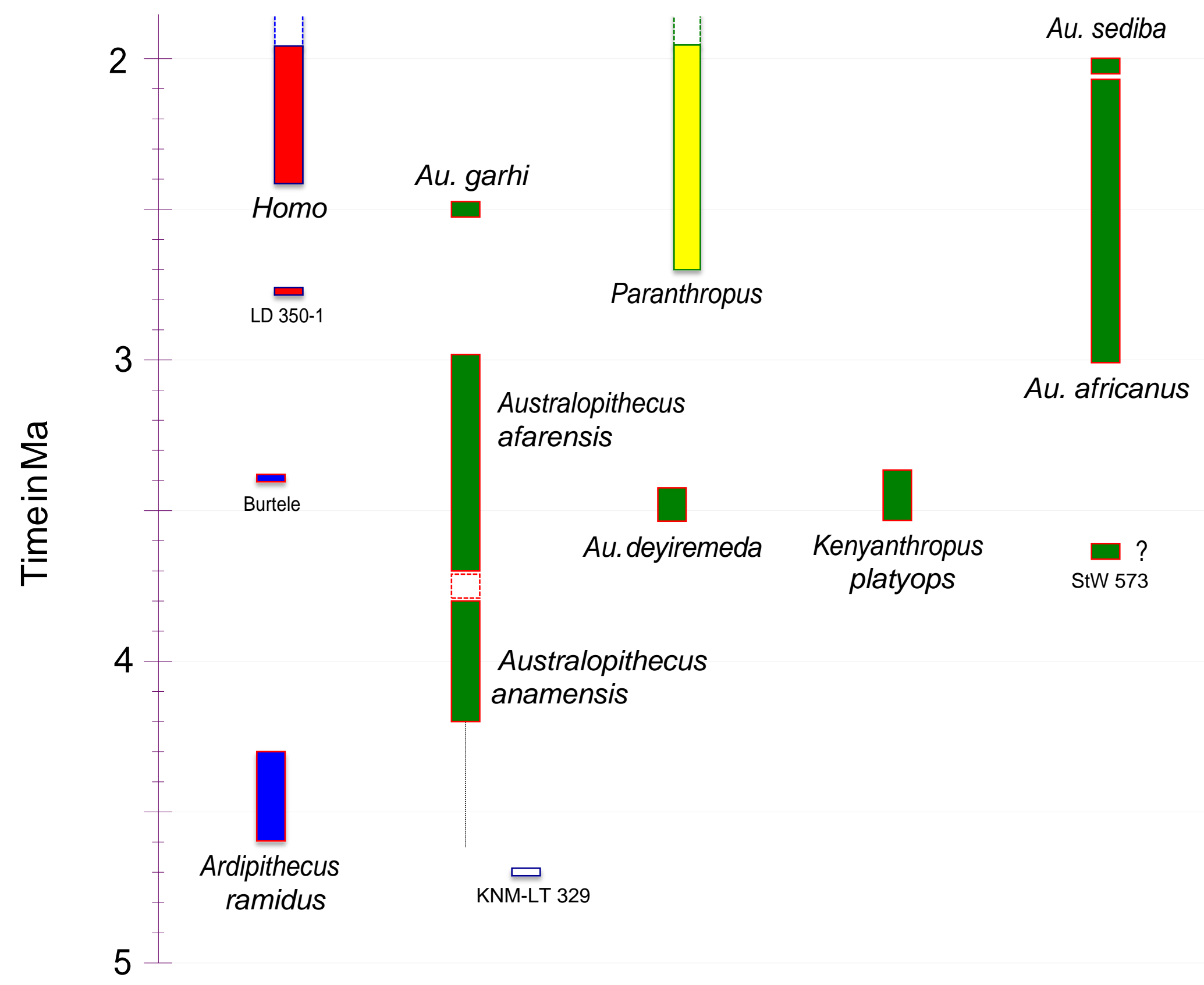




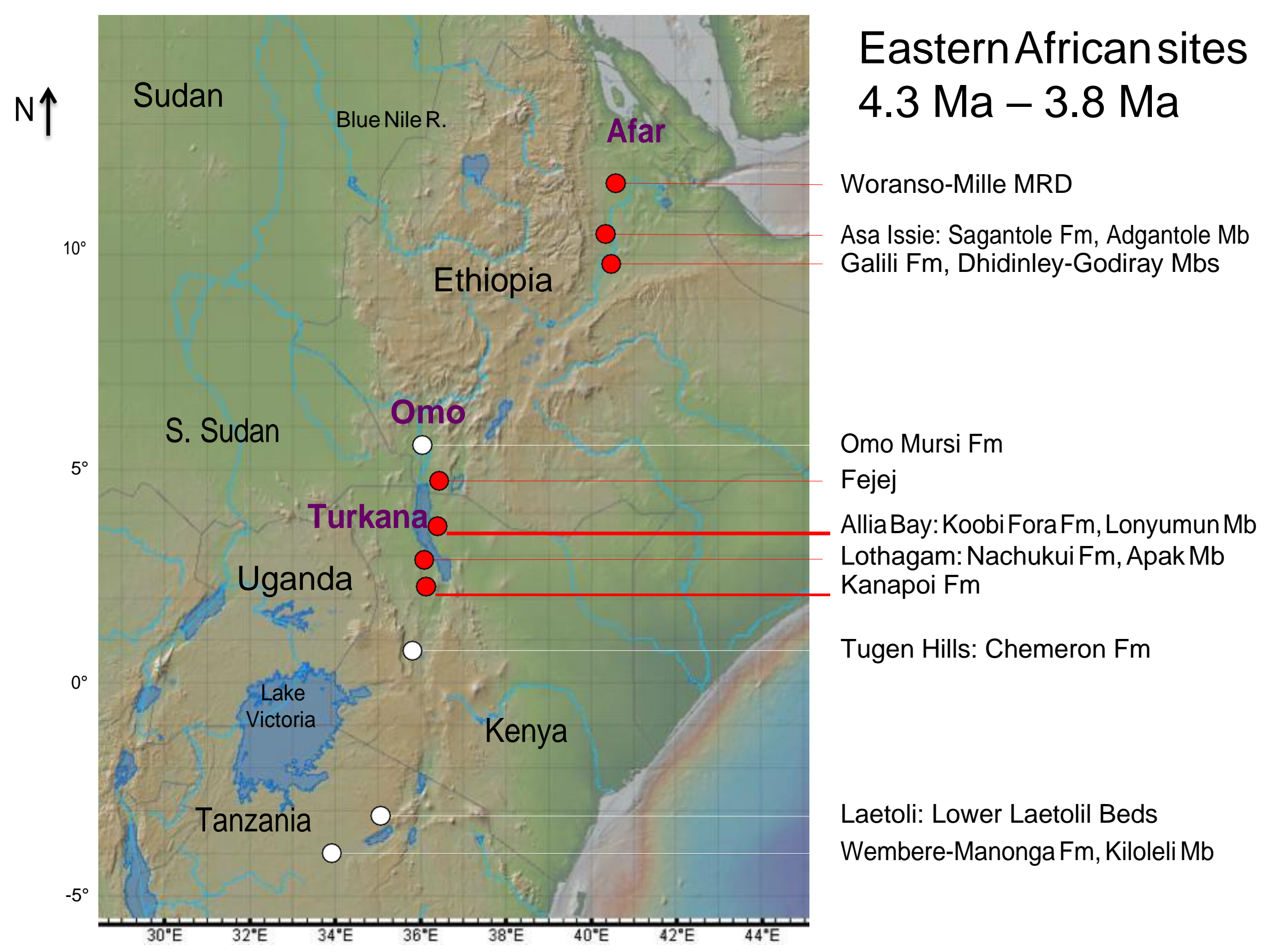




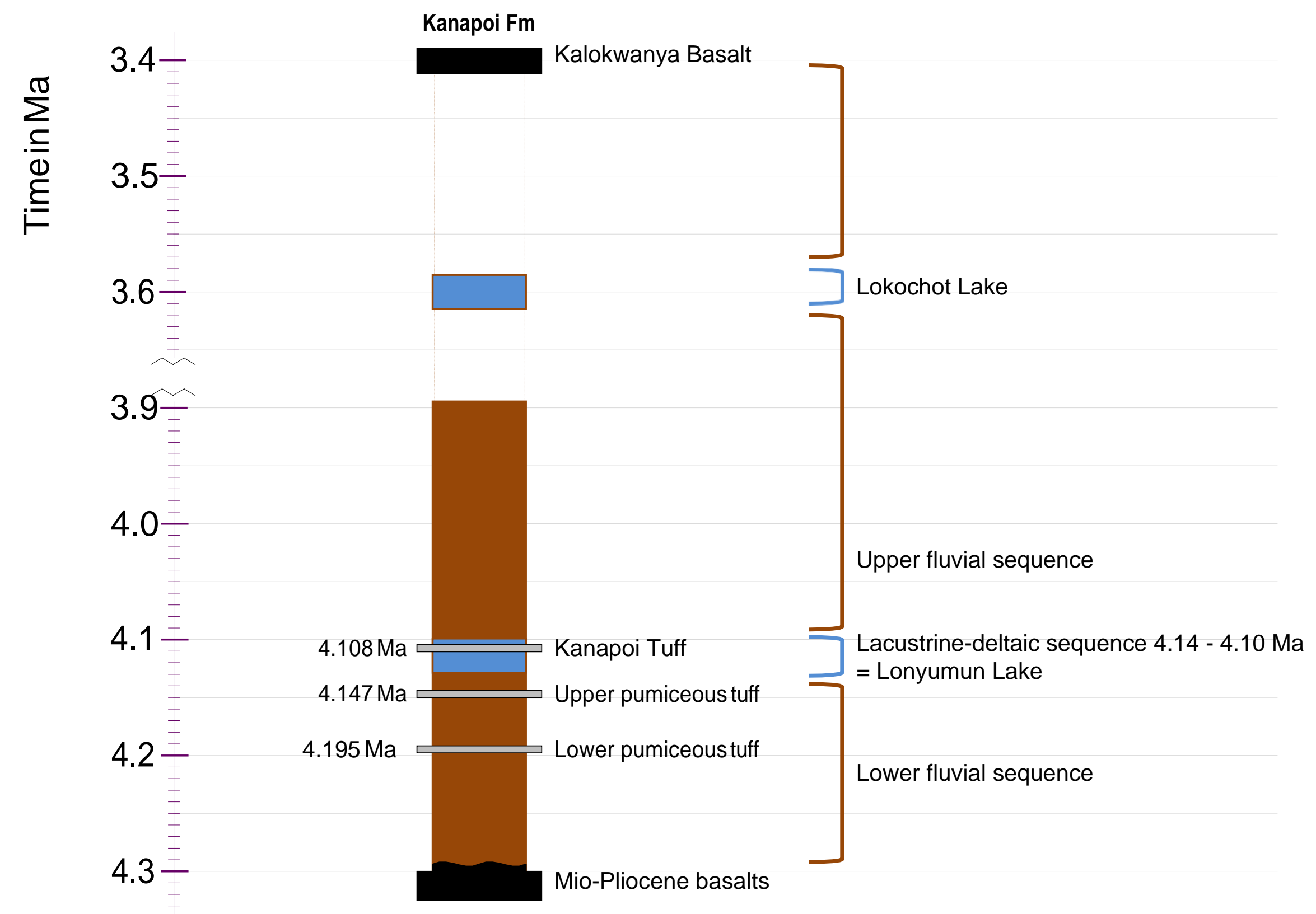




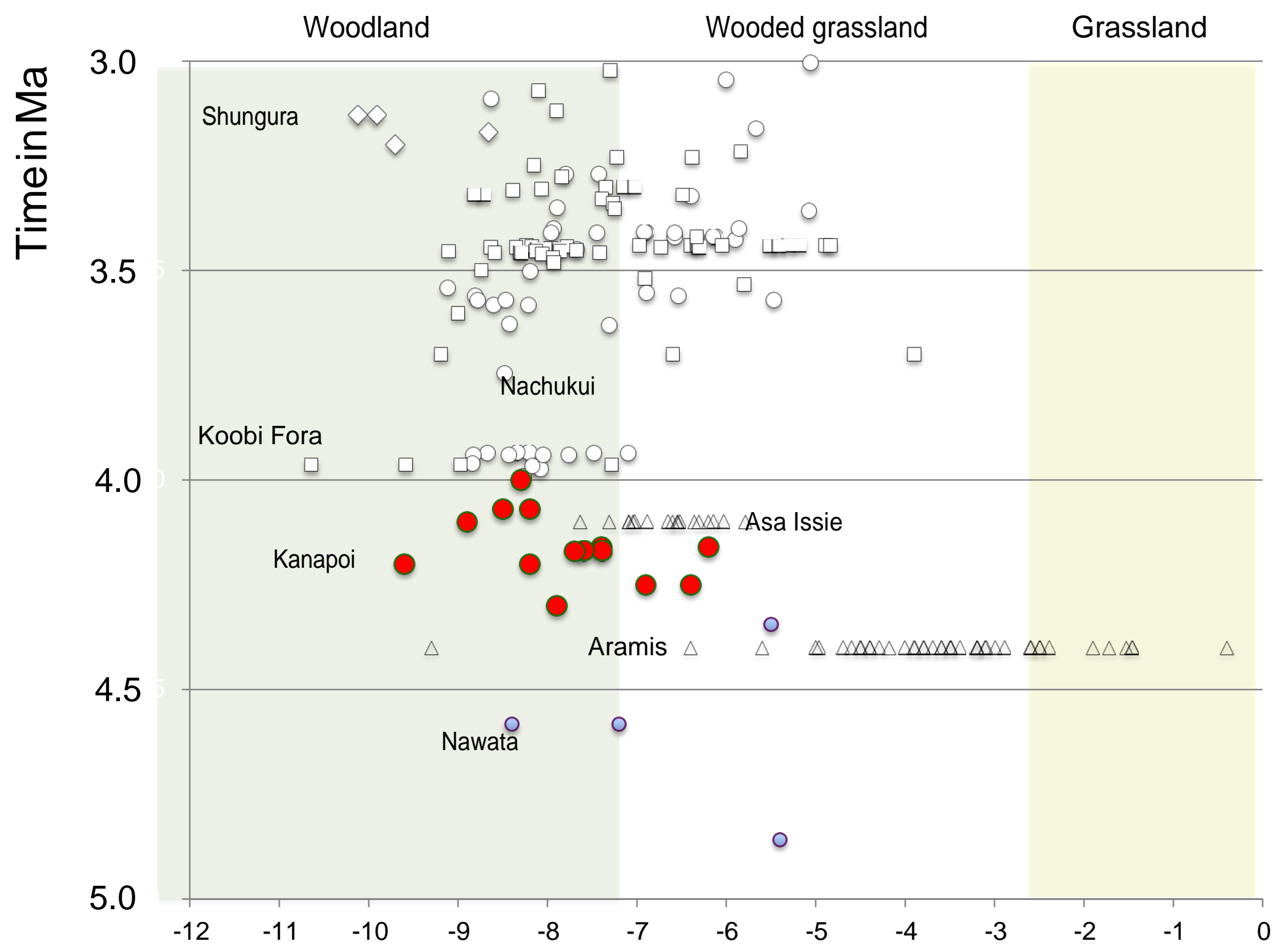

Paleosol carbonate $\delta^{13} \mathrm{C}$ in \% from key sites in the Pliocene of the Omo-Turkana Basin and the Afar. Published values from Wynn 2000, Levin 2013 database. 
Upper fluvial sequence $\mathrm{n}=441$

Lacustrine-deltaic sequence $\mathrm{n}=3568$

Lower fluvial sequence $\mathrm{n}=1503$
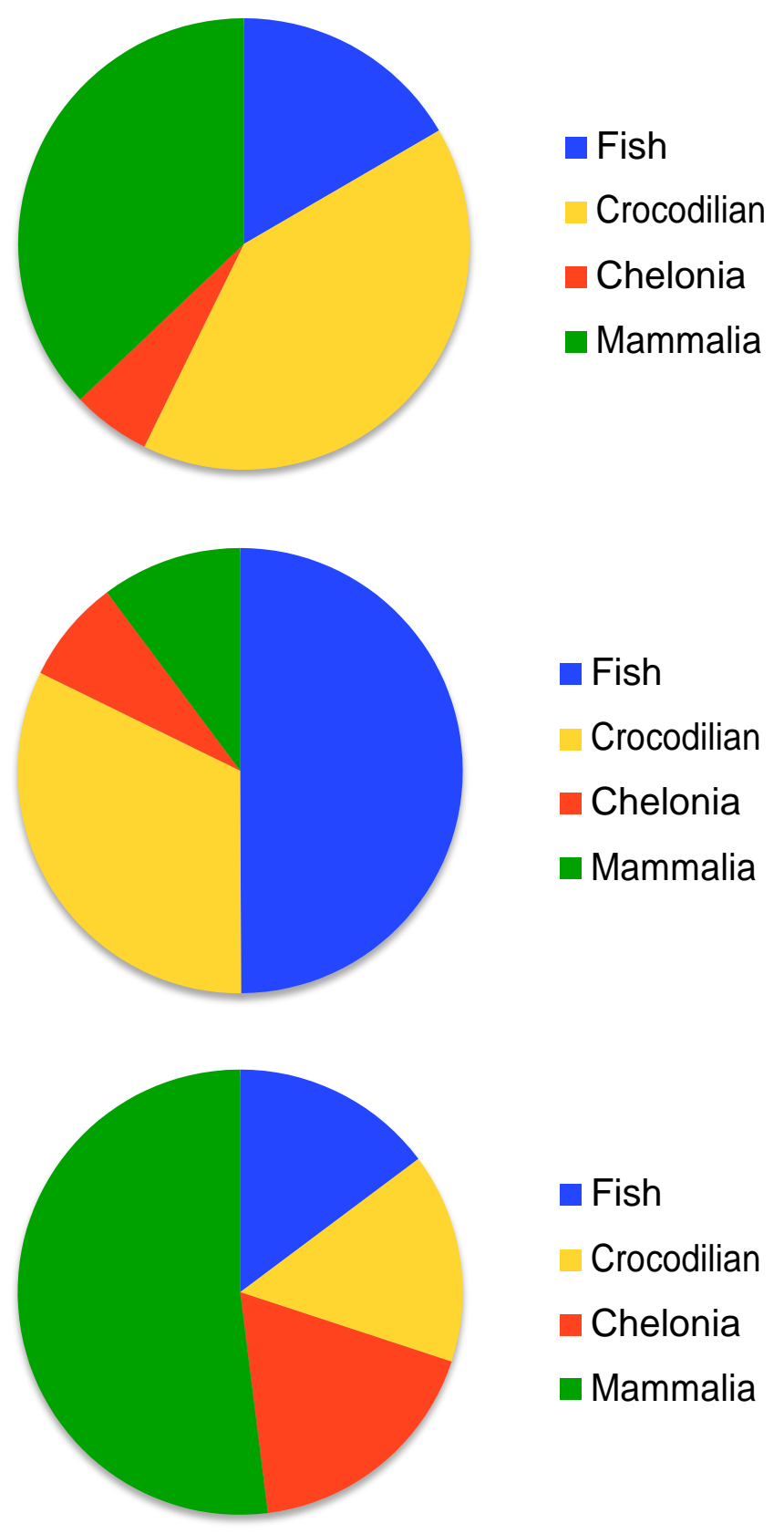

aish

Crocodilian

- Chelonia

- Mammalia 


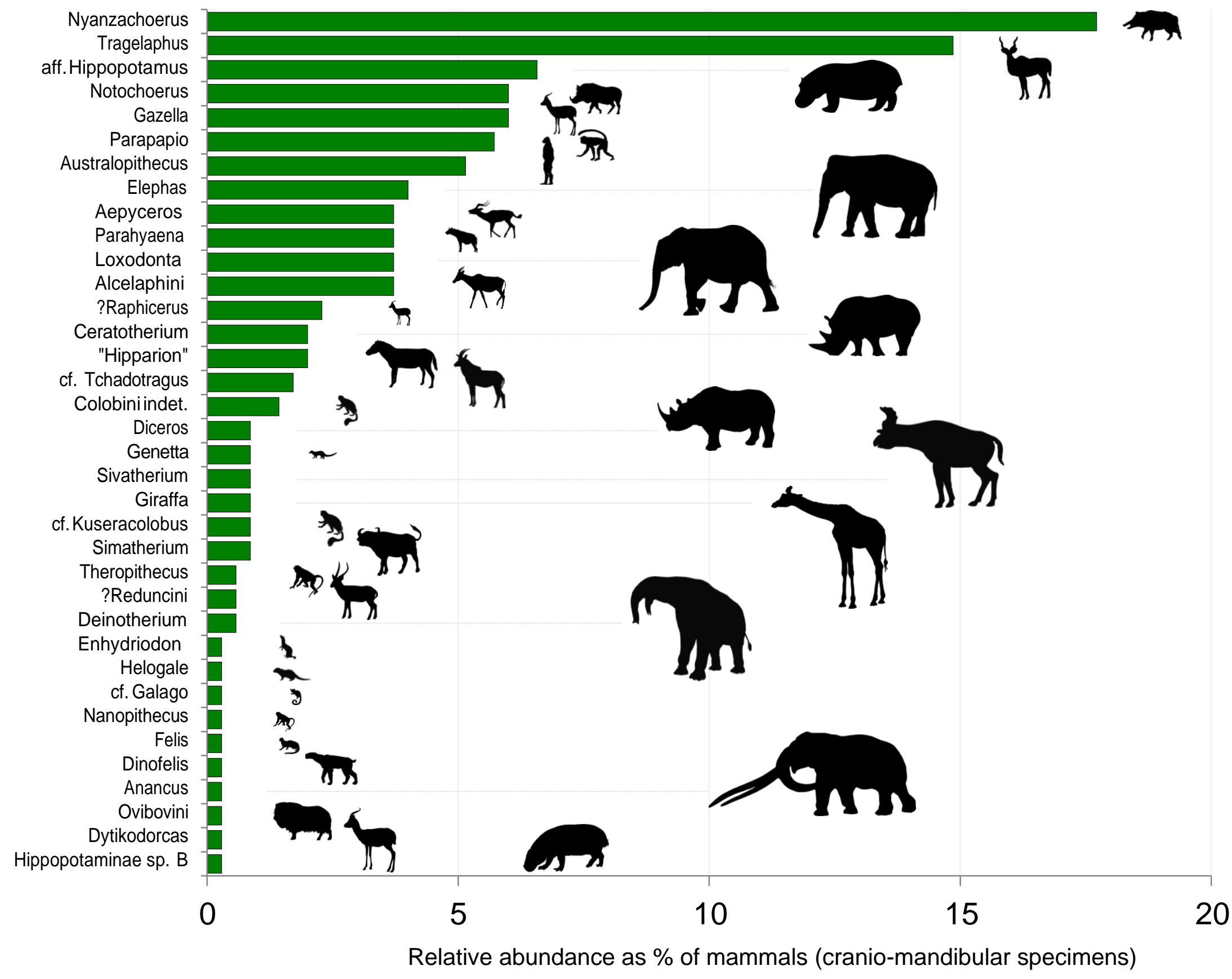




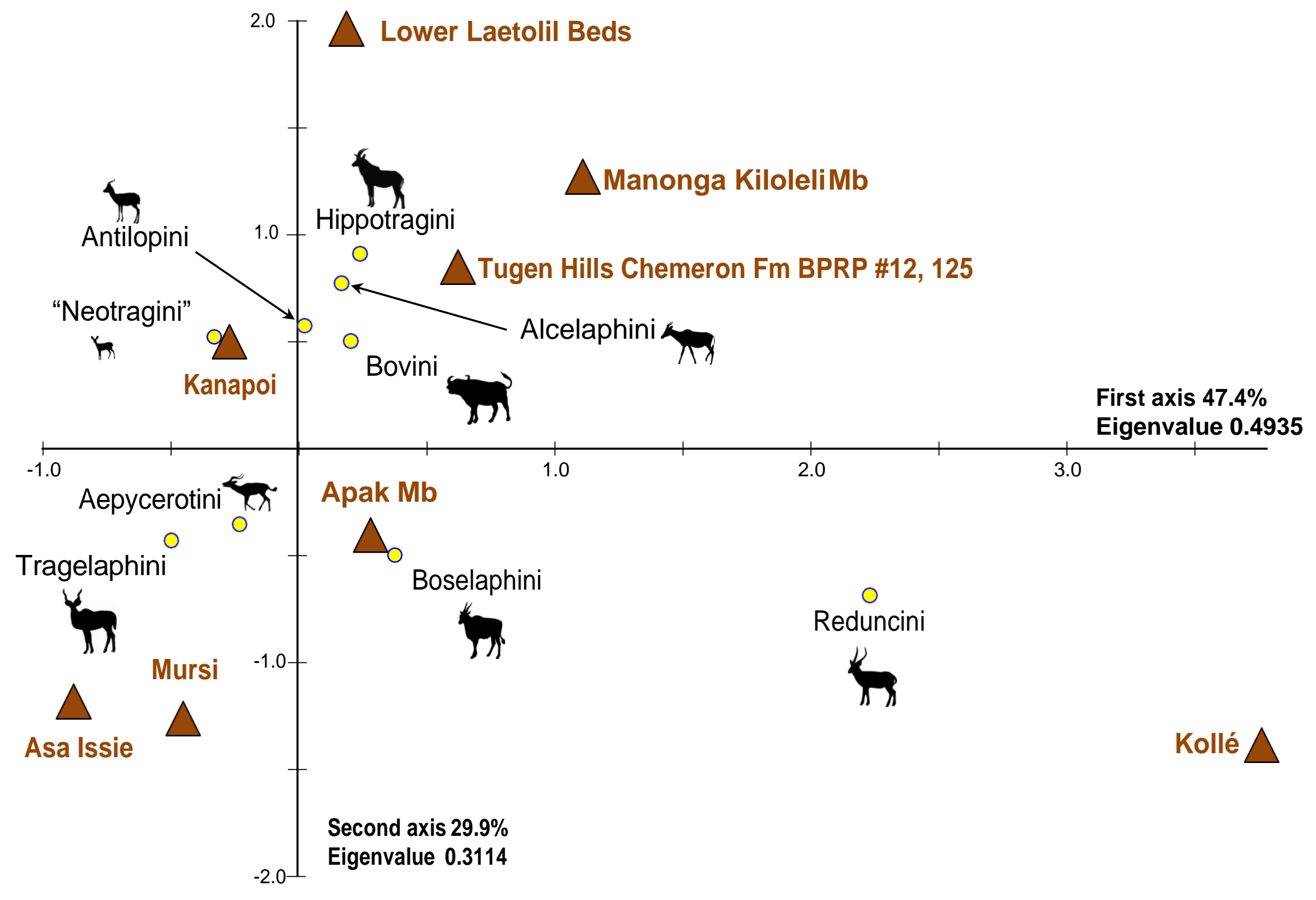


Hominin diets $\left(\delta^{13} \mathrm{C}\right)$ in eastern Africa (Ethiopia, Kenya, Tanzania)

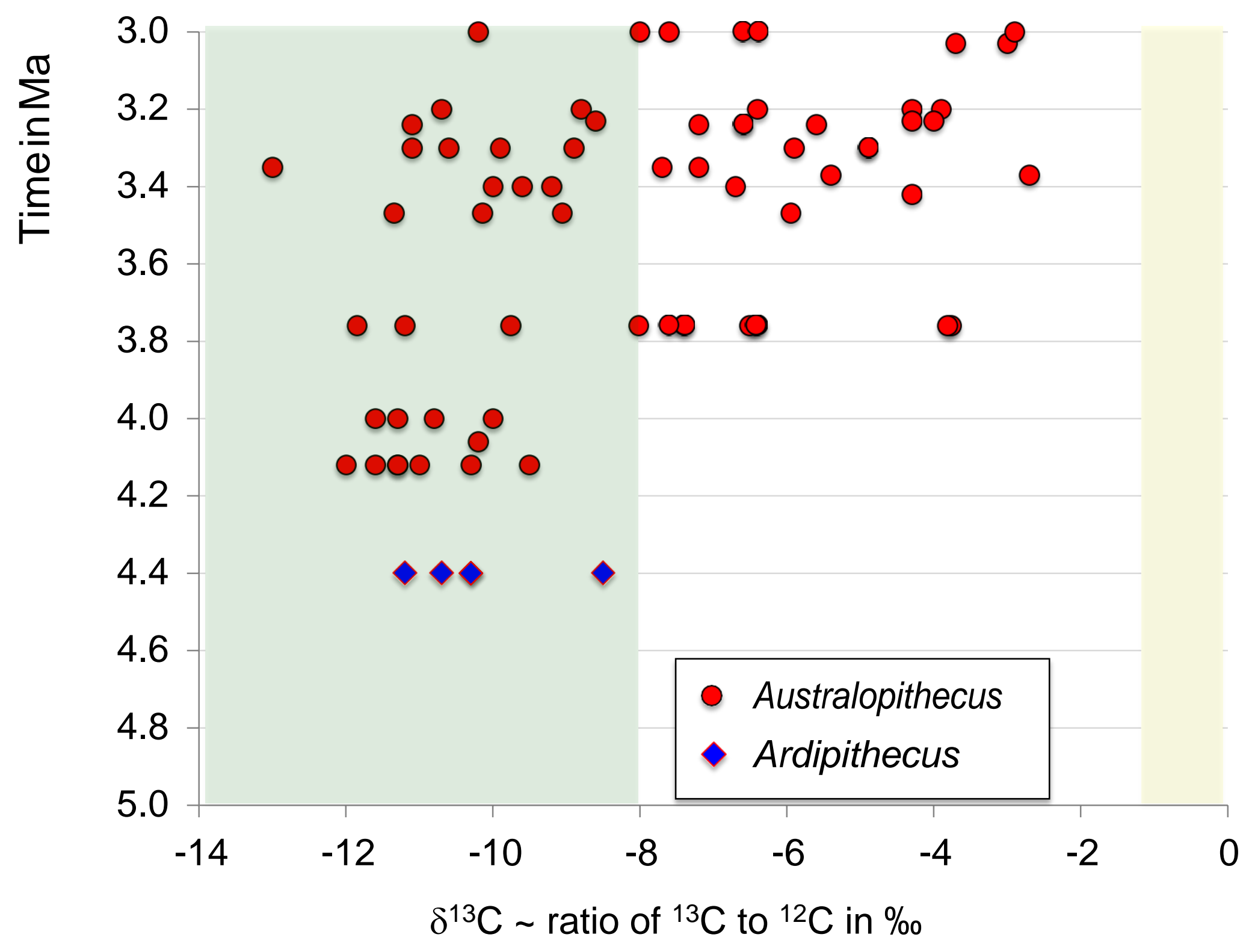

